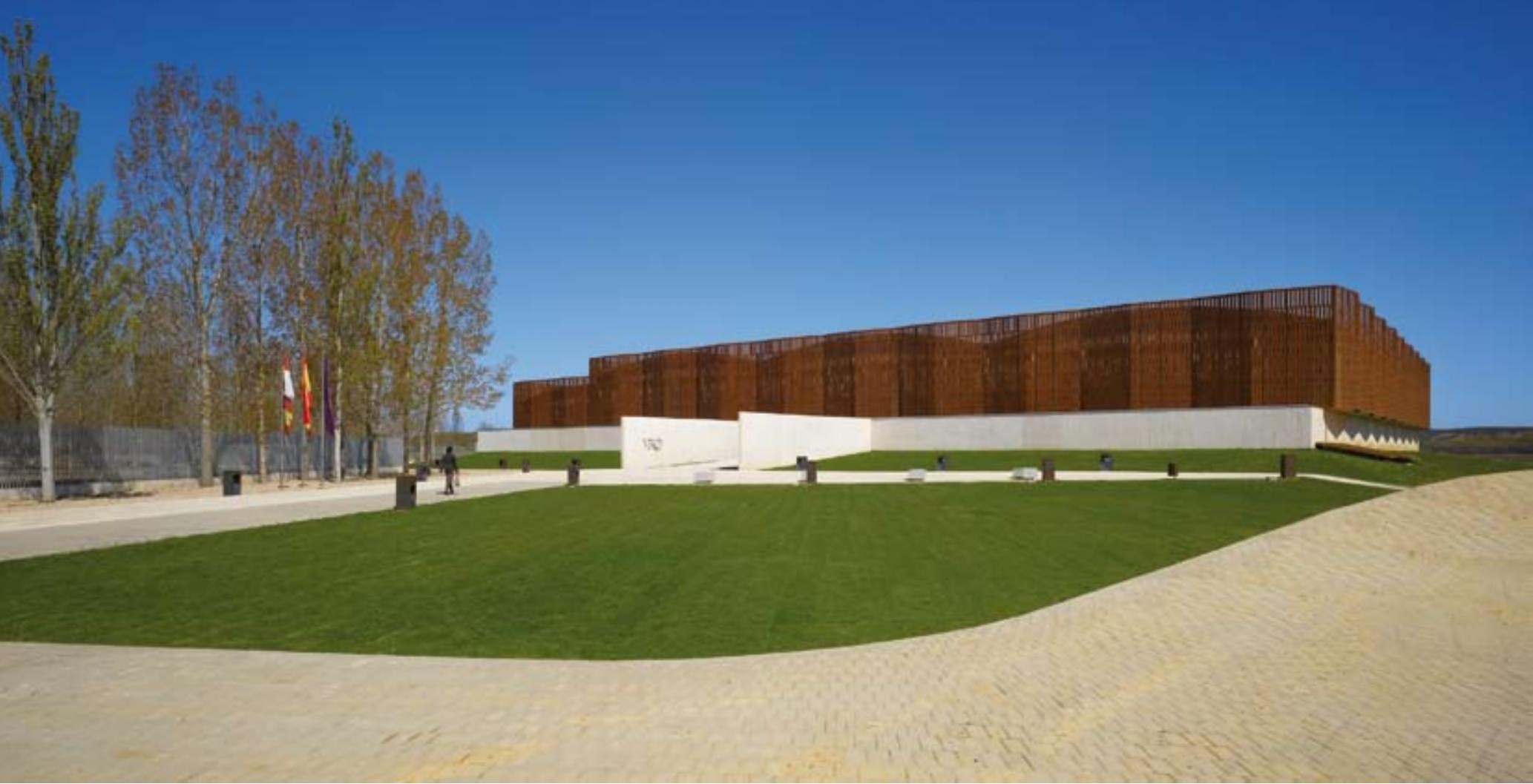

Museo de la villa romana La Olmeda (Pedrosa de la Vega, Palencia). Foto: Roland Halbe 


\section{Villa romana La Olmeda}

Ángela Garcia de Paredes, Ignacio G. Pedrosa,

Paredes Pedrosa Arquitectos

\section{Resumen}

La aparición casual de un mosaico al arar unos sembrados llevó al descubrimiento, en 1968, de la villa romana La Olmeda (Pedrosa de la Vega, Palencia) y en el año 2000, tras completar la excavación del yacimiento, se plantea su musealización. La protección de este recinto arqueológico es una intervención donde la antigüedad se confronta con la modernidad y la arquitectura con el paisaje. Desde estos conceptos, el proyecto pretende transmitir al visitante el carácter unitario que estos fragmentos tuvieron en el pasado.

El edificio se organiza en cuatro naves, a la vez cubierta y estructura, que cubren la villa y las termas. La extensa ocupación del yacimiento y la conveniencia de no tocar su huella decidió un sistema constructivo modular. El entramado estructural de la cubierta es de base romboidal de tubos de acero. Exteriormente se reviste de aluminio e interiormente queda visto como un artesonado que protagoniza el gran interior continuo.

Una pasarela enlistonada de madera organiza el recorrido y se ensancha y estrecha según los puntos de contemplación de los mosaicos; rodea el patio central de la villa e incorpora los distintos elementos del programa museistico. Dentro del recinto, se envuelven las distintas estancias de la villa con mallas metálicas favoreciendo la contemplación de los mosaicos iluminados en ámbitos diferenciados y recuperando espacialmente las estancias.

El cerramiento perimetral se proyecta con módulos de chapa metálica perforada, trasdosados con policarbonato traslúcido para proteger el recinto arqueológico y matizar la entrada de luz natural. Los troqueles del cerramiento de chapa varían su densidad según la altura para integrarse con el paisaje de choperas.

\section{Palabras clave}

Intervención / Mosaicos / Musealización / Pedrosa de la Vega (Palencia) / Protección / Proyecto / Puesta en valor / Villa romana La Olmeda / Villae / Yacimientos arqueológicos 


\section{AZAR Y NECESIDAD}

El azar llevó a Javier Cortes un 5 de julio de 1968 a descubrir un fragmento de mosaico y unos restos de muros entre las tierras de su propiedad que explanaba para preparar su cultivo. Un montículo en el paisaje plano de sembrados y choperas de la vega del río Carrión es un perfil no habitual. Primero, nos explicaba a los arquitectos, la maquinaria tropezó con una superficie dura y algo brilló, después apareció un fragmento de mosaico que pensó llevar a su casa en Saldaña. La curiosidad le llevó a limpiar y a seguir la superficie del mosaico y la intuición a comunicarlo rápidamente y a recabar la asistencia especializada del catedrático de Arqueología de la Universidad de Valladolid, Pedro de Palol. Las primeras tareas mostraron la importancia del descubrimiento, se realizaron trabajos de levantamiento y conservación de los mosaicos encontrados y de los arranques de los muros. Algunos de los paramentos, de alturas entre 40 y $80 \mathrm{~cm}$, conservan aún el tratamiento superficial de revoco en sus caras. A los pocos días de continuar la excavación y limpieza, no cabía duda: el hallazgo no tenía límite y mientras retiraba las tierras, Cortes era consciente de que en su vida habia un antes y un después de ese descubrimiento casual.

Javier Cortes, persona culta y sensible, dedicó desde entonces su vida a excavar esta villa romana del siglo IV, la más completa y hermosa de su época, en un paisaje inalterado cruzado por acequias y salpicado por chopos que, cada estación que transcurría desde el dia del descubrimiento hasta hoy, cambiaba de color y silueta. Según avanzaban las labores, hubo que construir sucesivas estructuras provisionales de cerramiento, que permitian proteger los restos arqueológicos y que aparecian en el paisaje como construcciones industriales. También se realizó una prospección general en los alrededores del yacimiento para delimitar su extensión, establecer su perímetro y buscar otras huellas de construcciones y necrópolis. Durante esos años Cortes no acepta las propuestas de traslado de los mosaicos a importantes museos y mantiene in situ el legado que cuidadosamente continúa descubriendo y que conduciria, tras años de trabajos ininterrumpidos, a rescatar la villa que hoy podemos contemplar. Hasta 1980, año en que cede el yacimiento a la Diputación de Palencia, la excavación se completa como una iniciativa personal y en 1984 se abre al público por vez primera.

El azar también nos llevó a nosotros a participar en el concurso de ideas arquitectónicas convocado para adecuar el yacimiento arqueológico en el año 2000, atraídos por el nombre del lugar, Pedrosa, y el objeto del proyecto que presagiaba un trabajo singular y atrayente. Y fue Cortes quien casualmente nos enseñó La Olmeda entonces, mezclados entre un grupo de turistas que visitaban el yacimiento. De sus palabras escuetas y precisas conocimos la importancia de la villa y del valor que tenía que estuviera intacta en el mismo lugar donde se descubrió. También quizá intervino el azar al ganar nuestra propuesta el concurso de ideas que nos vincula durante una década a esta villa romana.

El valor de La Olmeda (Pedrosa de la Vega, Palencia) reside en poder conocer la villa completa en toda la extensión de sus más de 3.000 metros cuadrados y sus mosaicos en el preciso lugar para el que se construyeron. La Olmeda es pues un museo necesario, construido in situ para un contenido valioso e inmueble, en el mismo lugar donde se levantó, seguramente rodeado por un paisaje similar al actual. Habia entonces gacelas y grandes ciervos, sus restos apa-

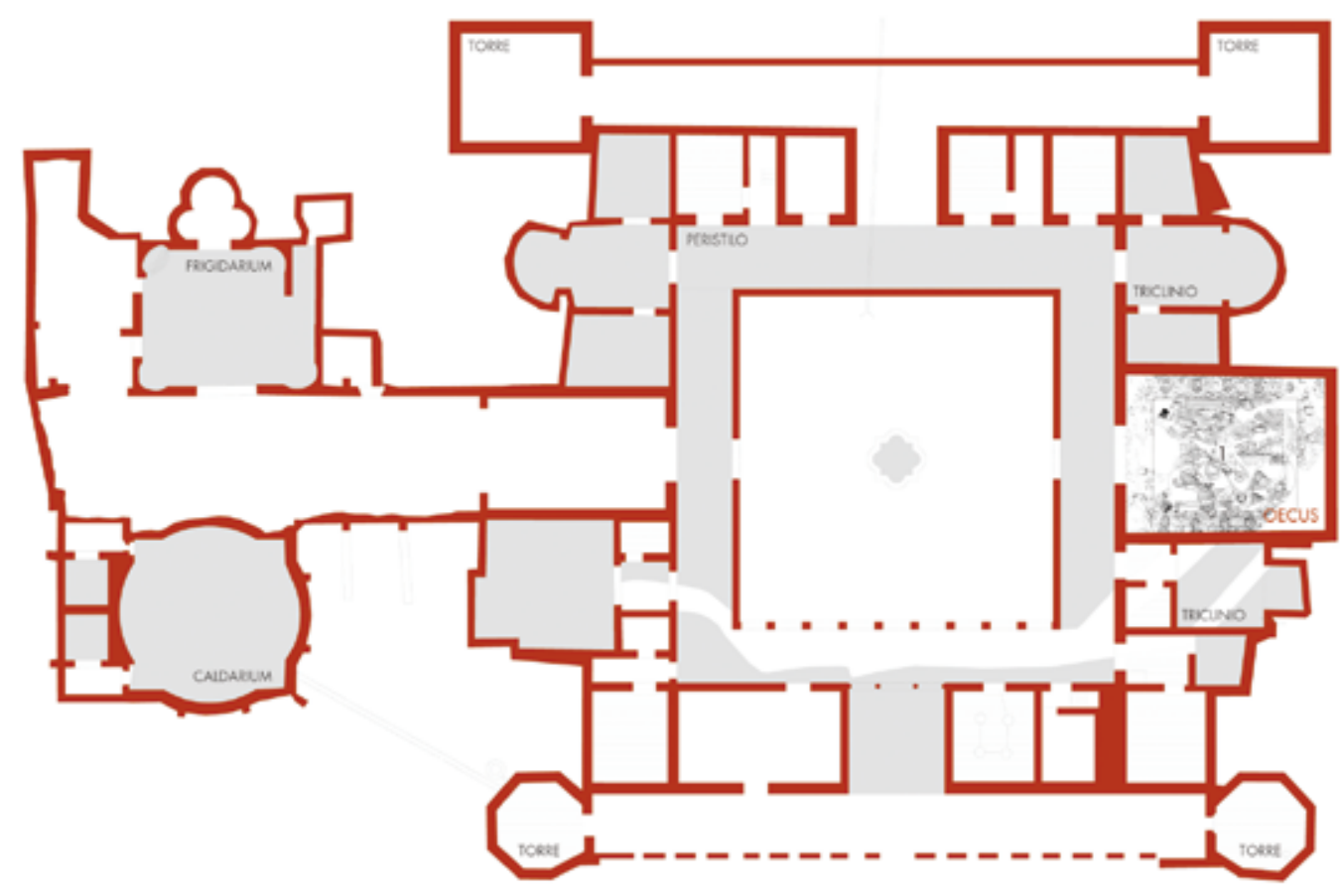

MUROS

MOSAICO $\quad 1.464 \mathrm{~m}^{2}$ OPUS SIGNINUM $303 \mathrm{~m}^{2}$ 
recieron también entre las tierras; pero también había trigo, girasoles y chopos como los actuales. Durante las obras aparecieron además, fuera de sus muros, bancadas de conchas de ostras, restos probables de selectos banquetes. Sus habitantes hablaban una lengua similar a la nuestra, quizá comprensible para nosotros, y leian nuestros clásicos. Su arquitectura y cultura eran próximas a las de nosotros, pero lejanas en el tiempo. Debiamos construir un espacio para contener ese tiempo y de esta forma el lugar arqueológico determinaba la construcción de un nuevo edificio.

\section{AROUEOLOGÍA}

Construir un museo del siglo veintiuno sobre la huella de una villa del pasado es el propósito del proyecto para La Olmeda. Si la Arqueología estudia el arte del pasado a través de sus restos, la Arquitectura debía materializar una villa palacio del bajo imperio romano sobre esas huellas con recursos actuales pero sin la ayuda de referencias de intervenciones similares. Sólo disponíamos de una planta canónica romana, los muros de una villa con un amplio patio central, posiblemente ajardinado y la traza de unas termas, desproporcionadas en tamaño, que se excavarian poco antes del comienzo de las obras del museo. Gran parte de las estancias estaban tapizadas con unos mosaicos intactos, delicados y coloristas, pavimento de unos espacios de arquitectura desconocida.

El conjunto de La villa La Olmeda, que ahora se muestra, se compone de dos elementos arquitectónicos diferenciados: la residencia y la zona de los baños, que se describen a continuación a partir de textos de José Antonio Abásolo, director de la excavación.

La residencia, inscrita en un cuadrado aproximado de 64 × 64 metros flanqueado por cuatro torres, estaba organizada en torno al gran patio jardín de $24 \times 24$ metros, bordeado en sus cuatro lados por galerias que conducen a las distintas salas y por habitaciones que componen la vivienda. En los laterales norte y sur, donde se encuentra el acceso a la villa y se disponen las estancias más pequeñas, la villa contaba con dos plantas. A esta segunda planta se accedía, posiblemente, por escaleras cuyos arranques son visibles entre los muros existentes. La disposición de los espacios de la residencia y la simetría del trazado, poco habitual en construcciones que normalmente se levantaban en distintas fases, son tan patentes que parece responder a un modelo canónico. En las esquinas las cuatro torres, dos octogonales en el frente sur de acceso y dos cuadradas en el norte, debian enfatizar su poderosa presencia monumental en el paisaje.

El acceso principal a la residencia se hace por el eje del pórtico sur, atravesando un atrio pavimentado con un mosaico geométrico y flanqueado el paso por parejas de columnas, de las que sólo quedan las basas. Al fondo del vestíbulo, está el acceso a la galería sur del peristilo, cuya separación con el jardín está formada por una arqueria de ladrillo, con nueve arcos de medio punto, hoy reconstruidos a partir de materiales originales hallados en la excavación.

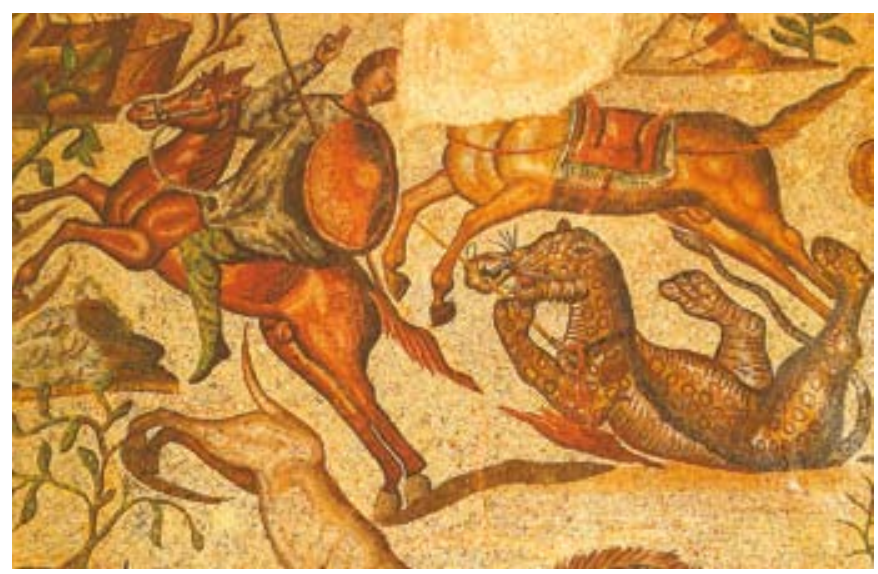

Escena de caza. Fuente: Documentación del Proyecto

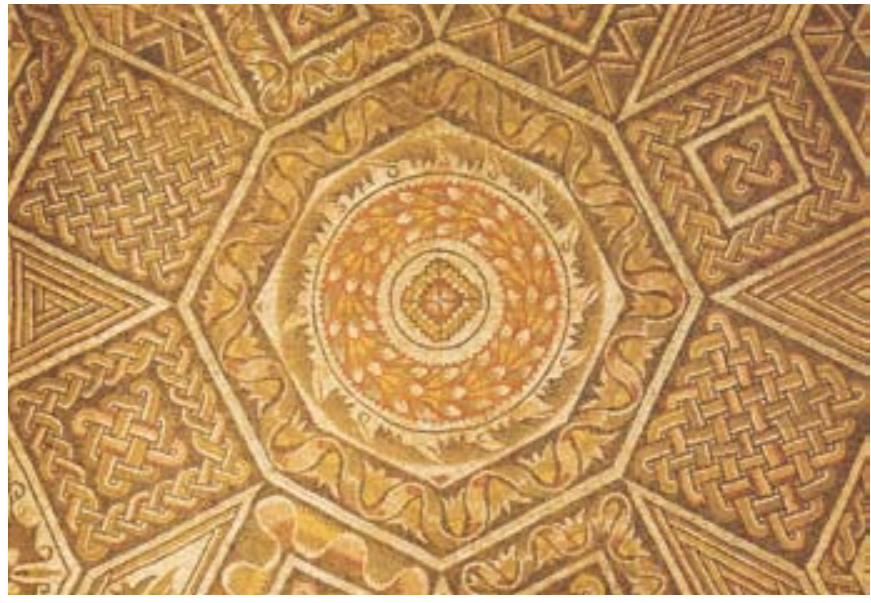

Mosaico con motivos geométricos y vegetales. Fuente: Documentación del Proyecto

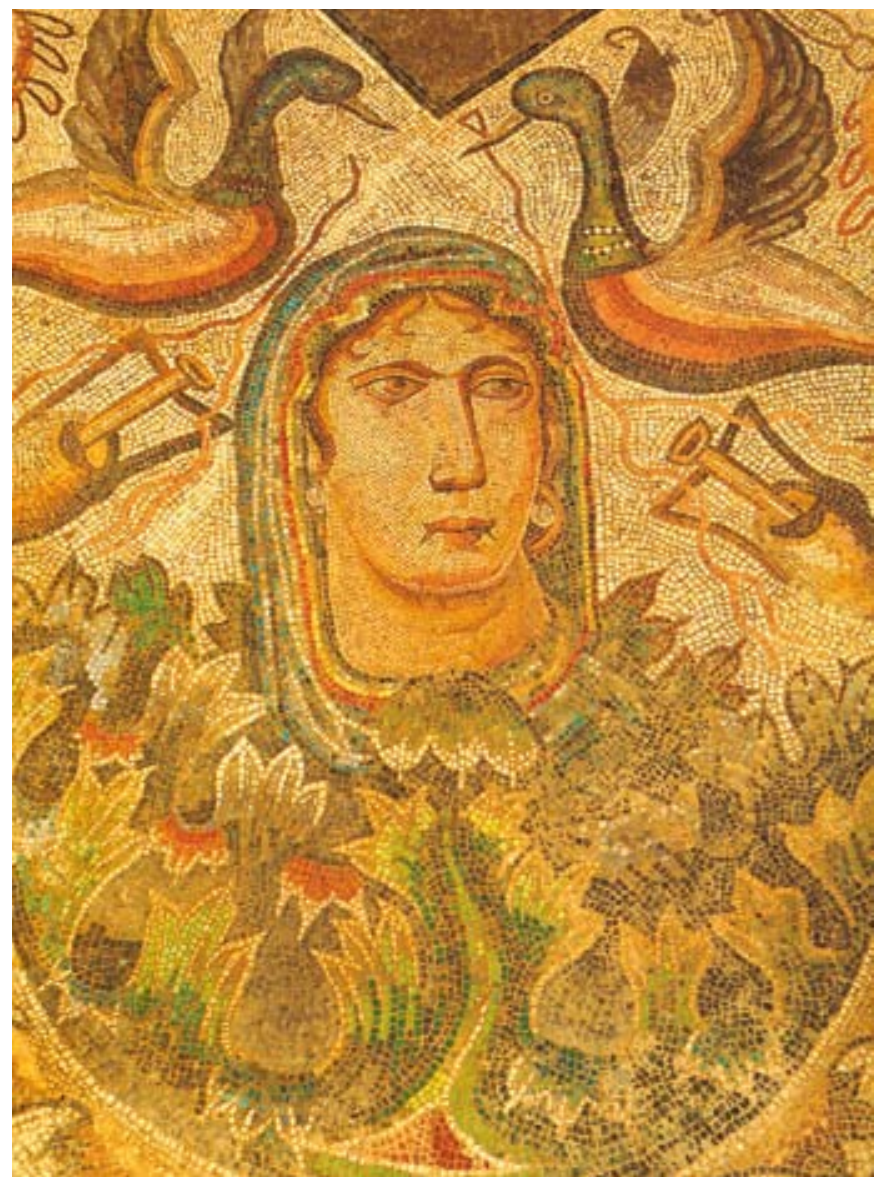

Detalle del retrato representado en el mosaico del oecus.

Fuente: Documentación del Proyecto 

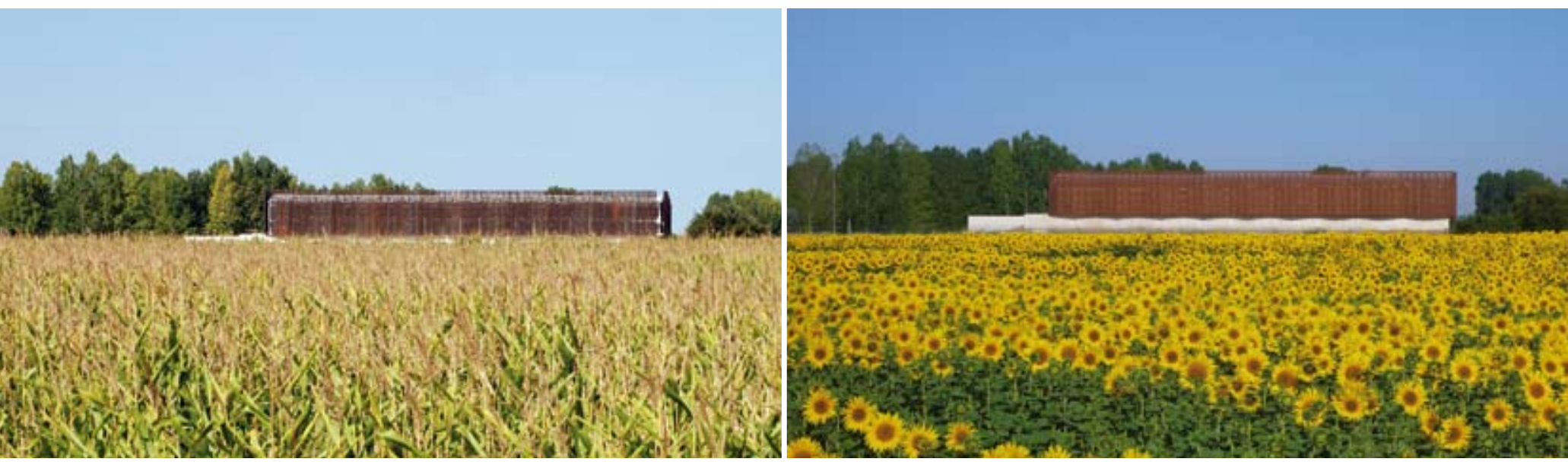

Primavera, verano, otoño e invierno. Fuente: Paredes Pedrosa Arquitectos

Los suelos de cada sala, junto a sus dimensiones, determinan la calidad de las habitaciones, de manera que aquellas destinadas a uso particular de los dueños y los de representación disponen de pavimentos de mosaico. En las áreas de servicio los pavimentos son de opus signinum (mortero de cal, arena y ladrillo) y de suelo de tierra apisonada para los almacenes, cocinas o habitaciones de servicio. Dispuestos simétricamente, en los ángulos de los corredores del peristilo que rodea el patio jardin, están los triclinia así como un cubiculum o dormitorio con una alcoba de servicio. En el ala este se disponen las estancias destinadas al dormitorio que se cree principal, más adelante el oecus y una habitación con ábside, todas ellas lujosamente pavimentadas con mosaicos. En la zona oeste destacan otros dos triclinios. El corredor norte, de 45 metros de largo, está rematado en sus extremos por dos torres cuadradas de 10 metros de lado y gruesos muros que indican una construcción de altura. Se accede al corredor por una estancia sin pavimentación desde el eje de la villa.

Los baños constituyen, por sus dimensiones, aproximadamente $900 \mathrm{~m}^{2}$, un conjunto arquitectónico con entidad propia. Son dos espacios diferenciados a ambos lados del corredor de acceso situado sobre el eje principal este-oeste que determina el oecus. Al norte se repite el itinerario clásico de las termas, públicas y privadas, anticipado por del peristilo. La fachada de entrada estaba formada por el propigneum, caldera que producia el aire caliente, y con las habituales zonas caliente, templada y fría, caldarium, tepidarium y frigidarium y, junto a este último, un apodyterium o vestuario que muestra tres pavimentos superpuestos: mosaico/mosaico/signinum. Tecnológicamente los baños disponian de sistema de desagüe y letrinas. Al otro lado del corredor de acceso existe una zona de descanso donde destaca una gran habitación de planta central compleja, intersección de círculo y cuadrado, de dimensiones aproximadas $14 \times 14$ metros, con hipocaustum, con la que limitan pequeñas estancias pavimentadas con mosaico que podrian cumplir la función de salas de masaje o unctoria. El sistema de calefacción subterránea, propio sólo de edificios públicos o de grandes y lujosas residencias, permitía que el aire caliente producido en un horno construido en el exterior del edificio fuera conducido por canalizaciones situadas bajo el suelo, cuyo pavimento se sustenta sobre pilas de ladrillos. La altura del espacio vacio por el que circulaba el aire caliente es de unos $50 \mathrm{~cm}$. En las termas, para obtener un calor más intenso, se integraban además en los muros tubos de barro cocido (tubuli), que daban salida al humo del horno y al aire caliente que circulaba en el hipocaustum.

Excepto el vestíbulo de acceso, las estancias del ala sur del palacio son habitaciones de servicio, entre las que se encuentran la cocina, un almacén y otras salas destinadas a uso agrícola o industrial impreciso.

En el eje del ala oriental del palacio se encuentra la sala principal, el oecus, de dimensiones aproximadas $16 \times 13$ metros, con los mosaicos de la escena de Aquiles y de cacería. En este mismo ala, se disponen un comedor con ábside rectangular, un pequeño dormitorio y tres habitaciones con hipocaustum, todas ellas pavimentadas con mosaicos geométricos de gran belleza y variación en sus temas. El ala norte del palacio se compone de una larga serie de habitaciones, sin mosaico, cuyo uso no podemos precisar y en cuyo eje se disponía el otro ingreso a la residencia. Las habitaciones del ala oeste del edificio tienen casi todas ellas mosaicos. Destaca el comedor principal, de forma muy irregular, posiblemente por haber sido ampliado en varias ocasiones, lo que explicaria los cuatro mosaicos de diferente dibujo que forman su pavimento. Junto a este comedor, se establece mediante un amplio corredor, con piso de tierra, la comunicación con las termas. Éste es un espacio arquitectónicamente incierto y se desconoce si estaba cubierto, o si era un patio donde realizar ejercicios al aire libre.

En el centro de la villa el patio jardín es prácticamente cuadrado, de dimensiones $24 \times 24$ metros. Tenía en su centro una fuente de mármol, de la que sólo se han recuperado algunos fragmentos, rodeada por un mosaico circular. Una pérgola de madera se apoyaría posiblemente en los dados recuperados y recrearia un jardín sombreado y fresco que centralizaría la vida de la familia en los cálidos veranos. 

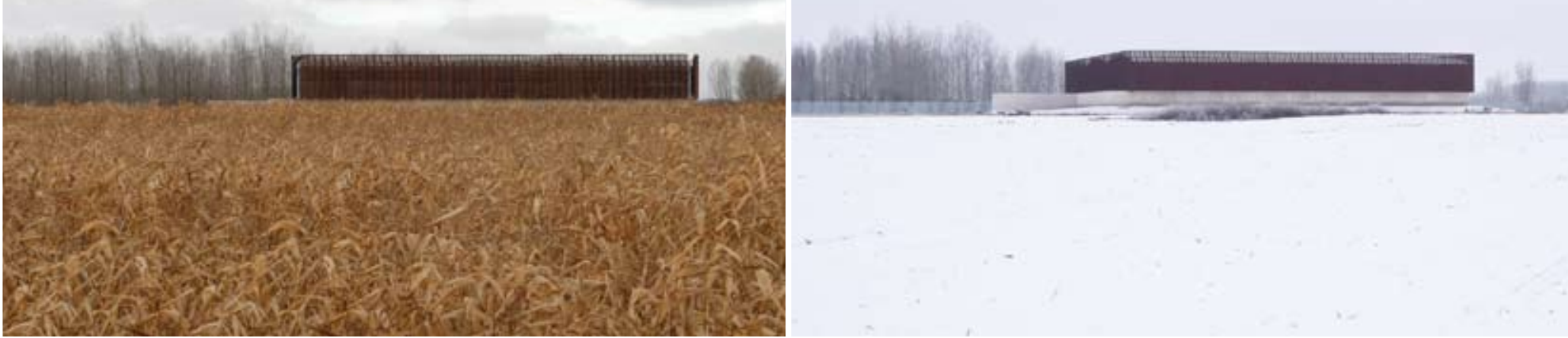

La mayor parte de los mosaicos son de diferentes diseños con una variada gama de dibujos, tramas de series repetitivas de motivos geométricos sencillos (nudos de Salomón, foliáceas, esvásticas, peltas o escudos...) hasta otras más complejas en las que se componen hexágonos, cuadrados y rombos. Estos pavimentos fueron confeccionados a lo largo de distintas fases y momentos, como lo indican tanto los diferentes estilos de los motivos utilizados como la existencia de mosaicos en espacios ampliados o modificados que no parecen atenerse al plan inicial.

En el gran salón de la villa, el oecus, se encuentra el mosaico más espectacular de los conservados. El oecus es una habitación de 174 metros cuadrados con funciones de representación. Su pavimento está completamente cubierto de mosaicos que da cuenta del estatus de los propietarios y su suelo es una auténtica alfombra multicolor realizada en opus tesellatum. Tanto su tamaño y su estado, como la calidad de su manufactura y la complejidad descriptiva del tema, le confieren un carácter singular. El centro del mosaico lo ocupan varios temas con figuras, rodeados por una rica cenefa geométrica. Entre los temas figurados, el más próximo al acceso es un conjunto de escenas de caza, en las que se pueden ver leopardos que luchan con cazadores, un jabali acosado por una jauría de perros, antílopes perseguidos por un león y otra serie de animales, tanto autóctonos como exóticos. Es la parte del mosaico que mejor se ha conservado. Dos motivos principales ocupan la parte central del pavimento del oecus. El mayor es una escena de asunto mitológico del ciclo troyano: Ulises descubre a Aquiles en el gineceo de Licomedes, rey de Skyros. La escena narra cómo Aquiles fue escondido por su madre Tetis entre las hijas del rey de Skyros, Licomedes, aprovechando sus rasgos femeninos y su pelo cobrizo. Así evitaría ir a la Guerra de Troya donde un oráculo había profetizado su muerte. Pero los griegos saben que sin el concurso de Aquiles no ganarán la guerra, y otro oráculo hace saber a Ulises que el héroe se esconde en Skyros. Ulises acompañado de dos soldados descubre a Aquiles mediante la estratagema de disfrazarse como vendedor de perfumes. Cuando lo identifica hace sonar las trompetas de guerra y Aquiles se delata porque instintivamente coge la lanza y el escudo, al tiempo que Deidamia, su amante, y las demás hijas de Licomedes le sujetan para impedir que se vaya.

Esta escena representada desde la Antigüedad, y de la que se conservan ejemplos que van desde la Domus Aurea de Nerón hasta mosaicos en Oriente Próximo, pasó también a la pintura barroca e incluso a la ópera. Su significado hay que ponerlo en relación, más allá del asunto mitológico, con un fin educativo. Se trata de explicar cómo el honor y el deber se imponen: Aquiles finalmente va a la guerra, aun a costa del sacrificio personal y de la muerte. Alrededor de esta escena hay una galería de retratos en medallones ovalados que cuelgan de unos imperdibles sostenidos por unos animales fantásticos (ánades con cabezas de delfín en la cola) que se supone corresponden a los retratos, masculinos y femeninos, de una excepcional calidad, de los propietarios de la villa, realizados con gran realismo y de los que se conservan catorce de un total de dieciocho que fueron en origen.

En las cuatro esquinas se sitúan las estaciones de las que sólo se conserva completa el invierno. Bajo todo ello se sitúa una escena de cacería, o más bien diversas escenas de caza superpuestas, algunas con paralelos en otros mosaicos de la época, donde vemos a infantes y jinetes cazando diversos animales de la fauna autóctona y africana. El conjunto de ambas escenas está enmarcado por una orla con motivos geométricos y vegetales muy similar a la que cubre el pasillo por donde se accede a la estancia. La calidad de este mosaico queda patente en su color, más de 40 tonos diferentes, en la aplicación de teselas de vidrio y otras recubiertas por metales preciosos, y en las minúsculas dimensiones de las piezas (alguna no supera los dos milimetros), lo que permite la ejecución de detalles con mayor precisión y acentuar el efecto de volumen.

\section{PAISAJE}

Las choperas de la vega del Carrión forman parte de los paisajes más característicos del Duero en Castilla y construyen un escenario que cambia continuamente según avanza o retrocede su repo- 
No hay más construcciones en el entorno. El edificio sobre La Olmeda no debía sobrepasar la altura de las arboledas y debía ser ligero y mimético con el lugar, como la silueta de una chopera. En los dibujos previos del proyecto está latente la imagen de la Capilla de Santiago de Sáenz de Oíza y Romany de 1954, como un objeto tecnológico y ligero sobre el paisaje de sembrados. De la misma manera que el paisaje urbano determina otros proyectos, en La Olmeda el edificio se vincula a la geometría oculta de la naturaleza y a la geometria de la propia huella del yacimiento.

Un muro perimetral de cuatro metros de altura de hormigón blanco con encofrado de tablilla vertical de madera envuelve la villa y las termas, retranqueándose al paso de una acequia y abriéndose en dos hojas en la entrada para incorporar el acceso en rampa ascendente hasta el nivel del recorrido museístico. El atrio acris-

Cerramiento modular de chapa de acero corten perforada de $2 \mathrm{~mm}$ de espesor talado del acceso abierto hacia el paisaje es el único punto del yacimiento en contacto visual con el exterior.

Mallas de tejido metálico

delimitando las estancias

con mosaicos

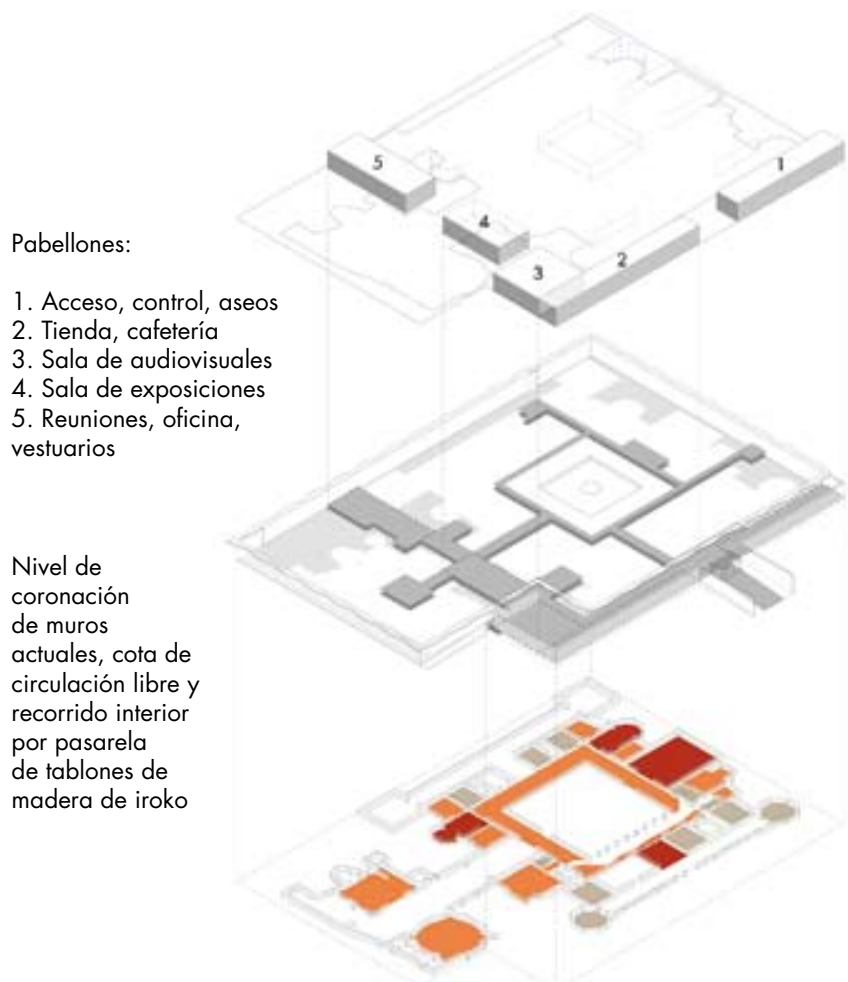

Yacimiento arqueológico romano

Sobre el muro, el cerramiento en altura se resuelve con módulos de chapa de acero corten perforada, trasdosada con policarbonato traslúcido para proteger del polvo del viento y de la siembra el recinto arqueológico y matizar la entrada de luz natural. Los troqueles del cerramiento de chapa varían su densidad según la altura abriéndose hacia la cornisa y el cielo, para integrarse con el paisaje arbolado. La envolvente de chapa se quiebra para ofrecer resistencia al viento y se despega del cerramiento interior traslúcido mediante una estructura tubular tridimensional que como grandes ramas de árboles sustentan el cerramiento metálico. En el interior el cerramiento provoca puntos de luz y sombra como si estuviéramos dentro de una gran chopera. Su condición libre de la estructura y del cerramiento da al gran volumen un carácter ligero, exento del suelo que quiere integrarse en el paisaje. Arropando el gran volumen, un talud vegetal lo ata al terreno y recuerda en el paisaje el montículo que durante siglos cubrió la villa y sus mosaicos.

La temperatura del lugar es extrema, desde el frío cortante que baja de la cercana cordillera cantábrica en invierno al intenso calor del verano cuando el color verde de chopos y sembrados es más brillante. El edificio contiene $60.000 \mathrm{~m}^{3}$ de ese mismo aire sin climatizar sobre la excavación. Dentro del yacimiento el aire está sólo detenido, protegido del viento en invierno y del sol en verano, es un exterior domesticado. El vestíbulo, comprimido en altura y revestido de listones de madera, configura el espacio intermedio interior entre el paisaje exterior y el nuevo espacio de la villa.

Superposición axonométrica de la intervención.

Fuente: Paredes Pedrosa Arquitectos

El paso de las estaciones está presente también en las cosechas cultivadas ante el edificio que con naturalidad se integra en el paisaje agricola. Los sucesivos meses de las obras nos permitie- 


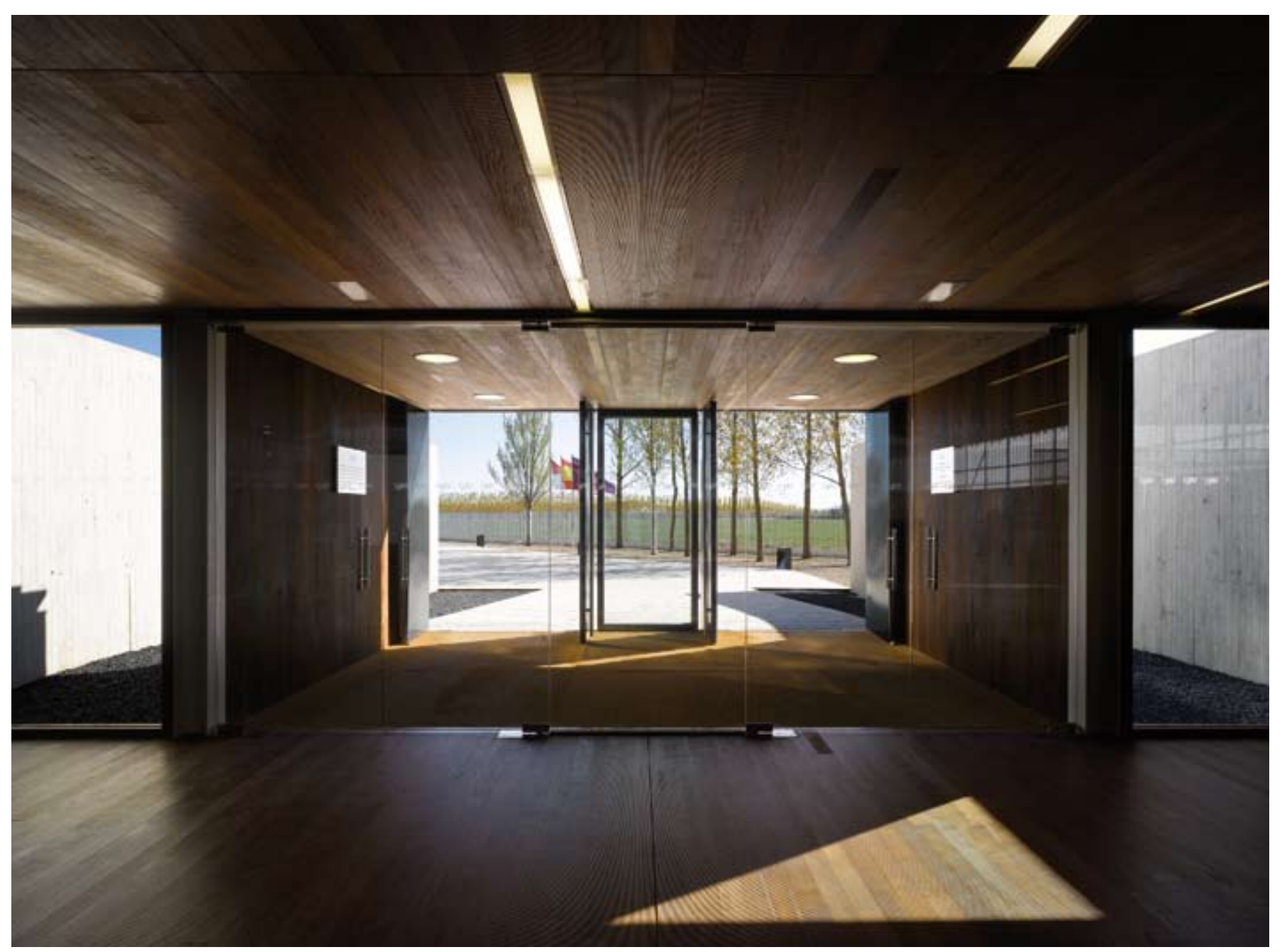

Vestíbulo. Foło: Roland Halbe

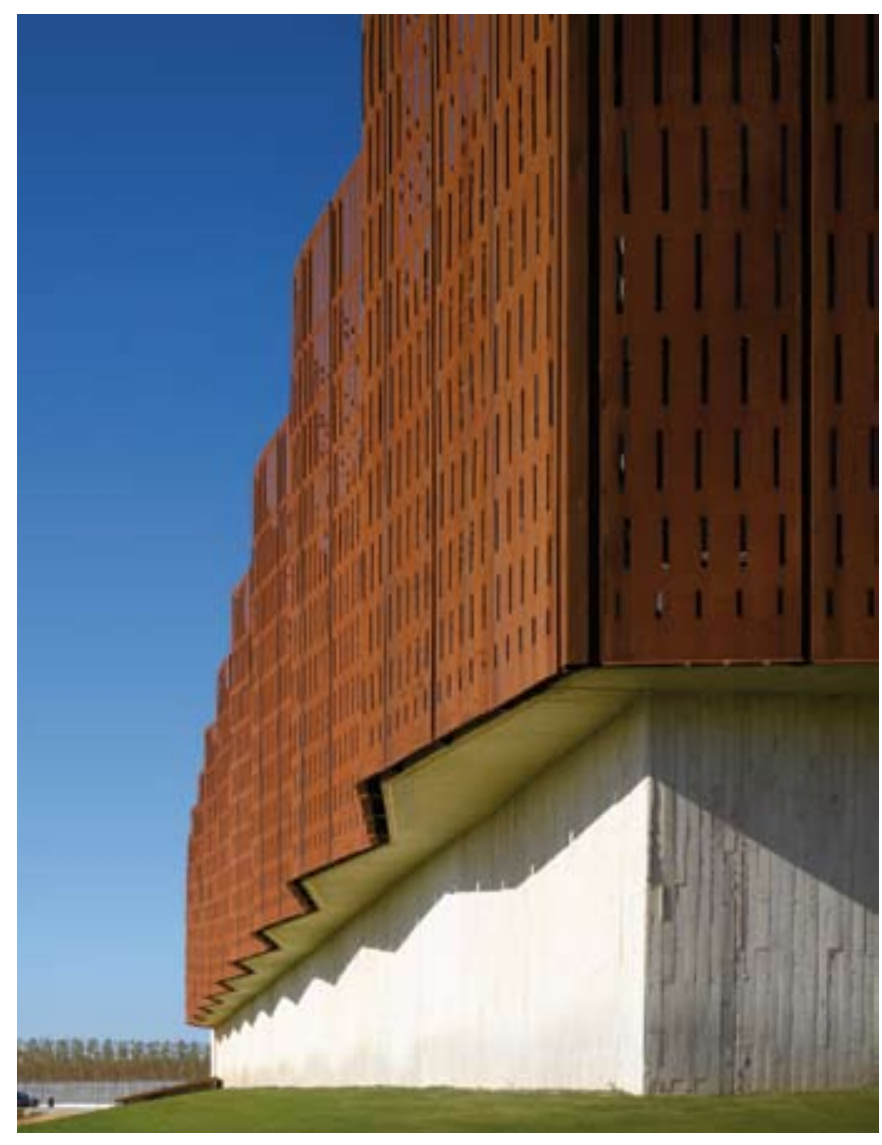

Detalle del cerramiento de acero corten. Foto: Roland Halbe

Plano de situación. Fuente: Paredes Pedrosa Arquitectos 

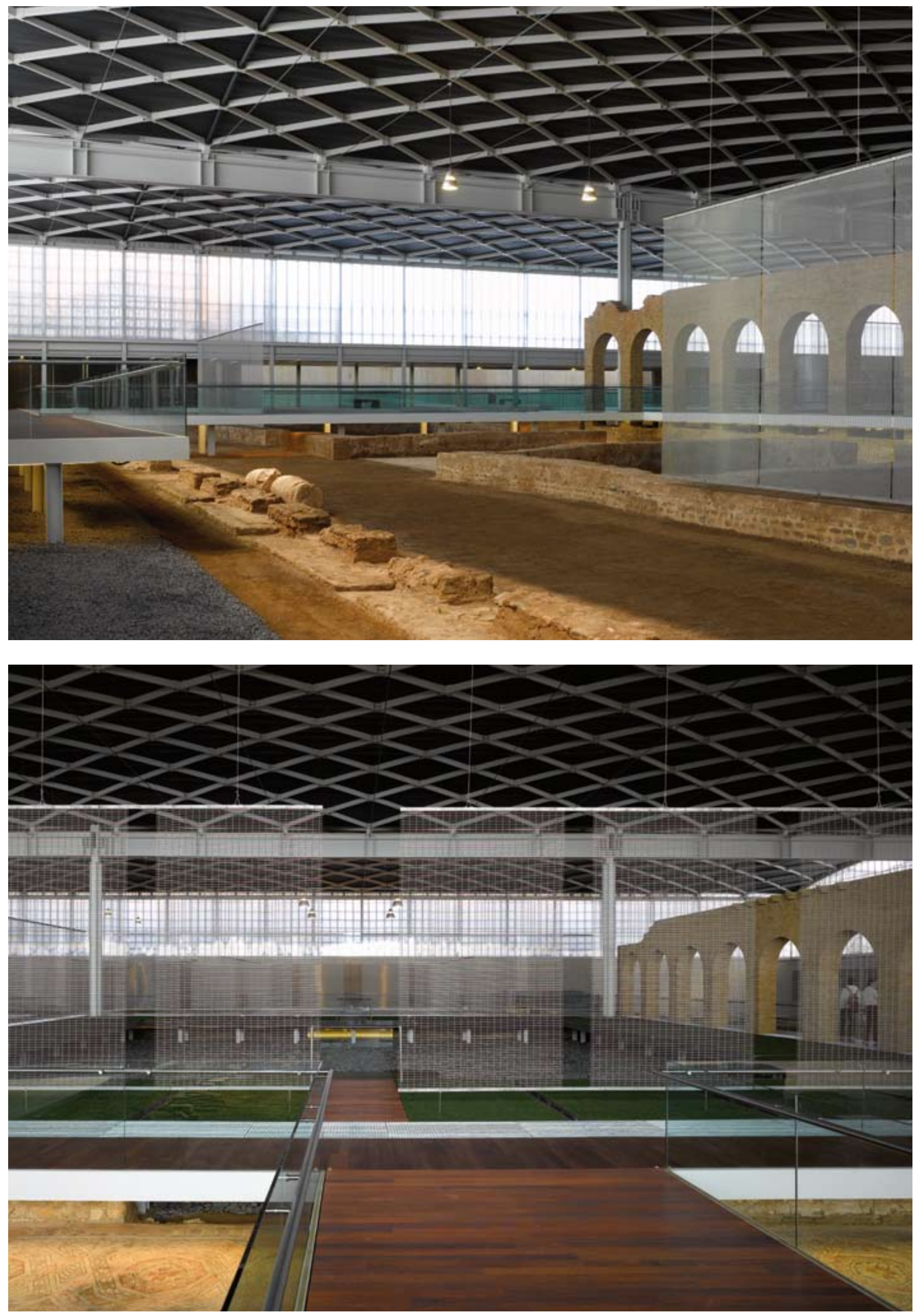
ron admirar esta naturaleza: campos verdes, campos de girasoles, campos segados, campos anegados o campos nevados. De esta manera un lugar arqueológico se convierte en una construcción del paisaje.

\section{FRAGMENTOS Y UNIDAD}

De La Olmeda los arqueólogos descubrieron las trazas de la villa y el plano horizontal de los mosaicos que la pavimentaban pero para nosotros era esencial construir no sólo un espacio para albergar el yacimiento, sino transmitir al visitante el carácter unitario que estos fragmentos tuvieron en el pasado. Encontrar la solución adecuada implica entrelazar los muros arqueológicos con la nueva arquitectura que quiere dar una imagen unitaria que permita comprender en conjunto la extensión y complejidad de la villa.

El recinto arqueológico se organiza en cuatro naves, a la vez cubierta y estructura, que cubren el yacimiento, tres para la villa y otra de menor altura para las termas. Las bóvedas 2, 3 y 4 , correspondientes a la villa, se apoyan sobre cuatro pilares metálicos exentos en las esquinas del patio jardín y en otros soportes menores en el perímetro, ocultos tras el cerramiento de policarbonato, que dan a la gran cubierta un aspecto de ingravidez. La bóveda 1 sobre las termas tiene un carácter autónomo y permite ver en toda su extensión el perimetro lobulado de los baños. Entre la villa y las termas un espacio intermedio de altura comprimida configura la conexión desconocida entre ambas construcciones y articula el recorrido del visitante.

El interior se plantea pues como un gran recinto continuo, dentro del cual se integran, sin romper esta continuidad, los distintos elementos que han de constituir el programa del museo bajo la ligera cubierta nervada. La estructura se construye con piezas romboidales e independientes de perfiles acero que atornilladas entre si reproducen, como las teselas de los mosaicos, una imagen única común a toda la villa. Una pasarela de madera de tablas de ipe rayado, siempre horizontal, se dilata y comprime según los puntos de contemplación de los mosaicos y contribuye a dar continuidad sobre los muros romanos. Tanto la cubierta como el plano de la pasarela construyen un lienzo neutro que traba en un conjunto unitario elementos aparentemente celulares.

La reconstrucción de la espacialidad de las estancias romanas era una premisa carente de referencias construidas. Salvo en casos como la villa del Casale en Piazza Armerina, Sicilia, donde se reconstruye casi literalmente el perimetro de los muros romanos sugiriendo el volumen posible de la villa, no existen ocasiones de musealización tan completos y amplios como la villa de La Olmeda. Las estancias recuperan su tercera dimensión mediante mallas de acero que restituyen idealmente los espacios originales de las salas. A través de las cortinas metálicas se intuyen y

\section{En el interior el cerramiento provoca puntos de luz y sombra como si estuviéramos dentro de una gran chopera (...) Las estancias recuperan su tercera dimensión mediante mallas de acero que restituyen idealmente los espacios originales de las salas}

perciben las dimensiones de las habitaciones sin interferir con la transparencia del conjunto. Éstas se descuelgan de la cubierta y favorecen la contemplación de los mosaicos iluminados en ámbitos diferenciados explicando su organización. Las estancias pavimentadas por las teselas, recuperada su tercera dimensión mediante los velos metálicos, se iluminan puntualmente enmarcando los mosaicos. Se quiere asi presentar al visitante un organismo complejo en el que se descubren las zonas excavadas y las diversas estancias que forman la villa, evitando dominar de un solo golpe de vista toda la excavación.

Un fragmento del mosaico de Ulises en el oecus indica los motivos empleados en el proyecto: un arco sobre la escena central y unas cortinas tras las que Aquiles se oculta.

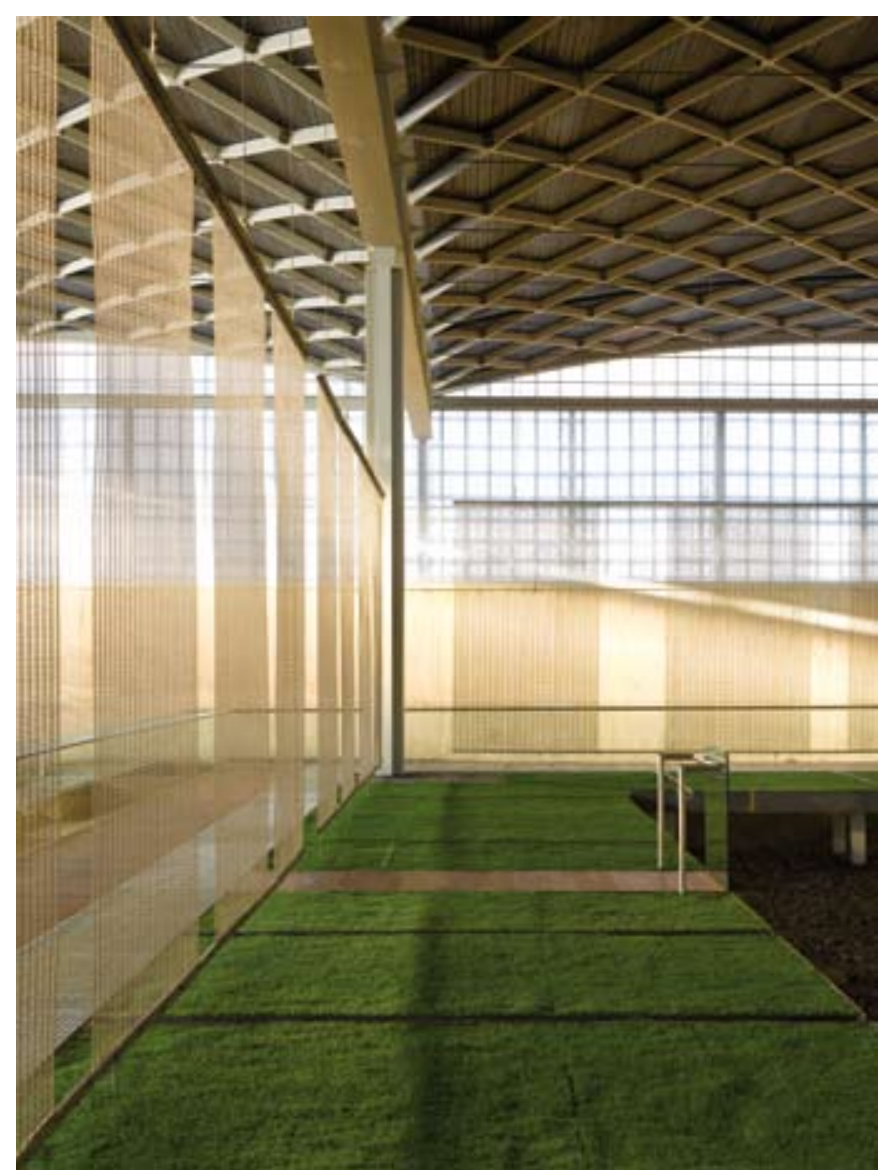

Cerramiento de cortinas metálicas en el patio central. Foto: Roland Halbe 

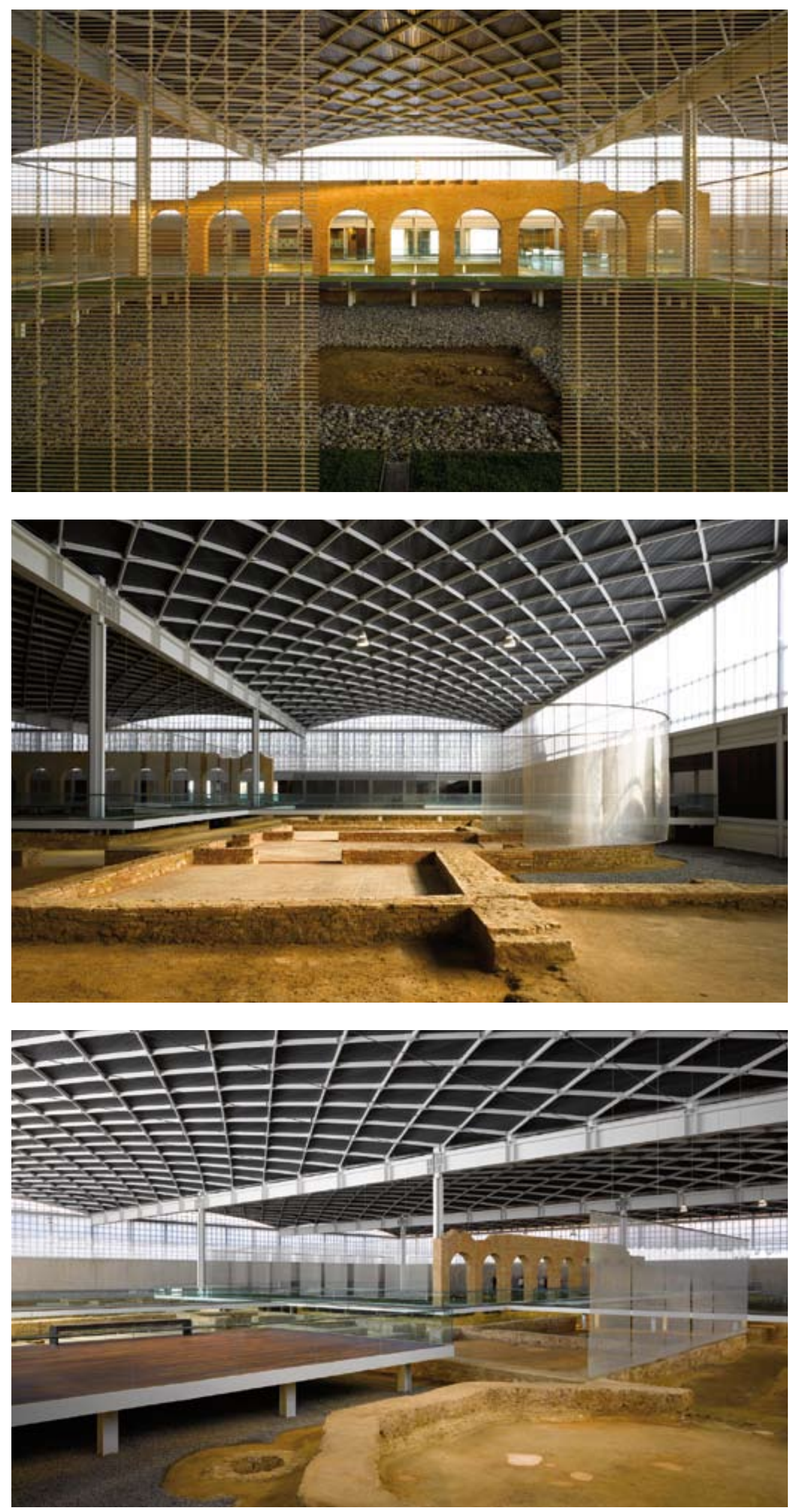
PROGRAMA

$\begin{array}{ll}\text { Acceso } & 01 \\ \text { Control } & 02 \\ \text { Almacén } & 03 \\ \text { Aseos } & 04 \\ \text { Patio-Carga descarga } & 05 \\ \text { Vestuarios } & 06 \\ \text { Oficina } & 07 \\ \text { Sala de reuniones } & 08 \\ \text { Sala de exposiciones } & 09 \\ \text { Audiovisuales } & 10 \\ \text { Almacén cocina } & 11 \\ \text { Office } & 12 \\ \text { Cocina } & 13 \\ \text { Cafeteria } & 14 \\ \text { Salida } & 15 \\ \text { Tienda } & 16\end{array}$

MOSAICOS DE

LA VILLA

Mosaico principal

Opus Signinum

Mosaicos
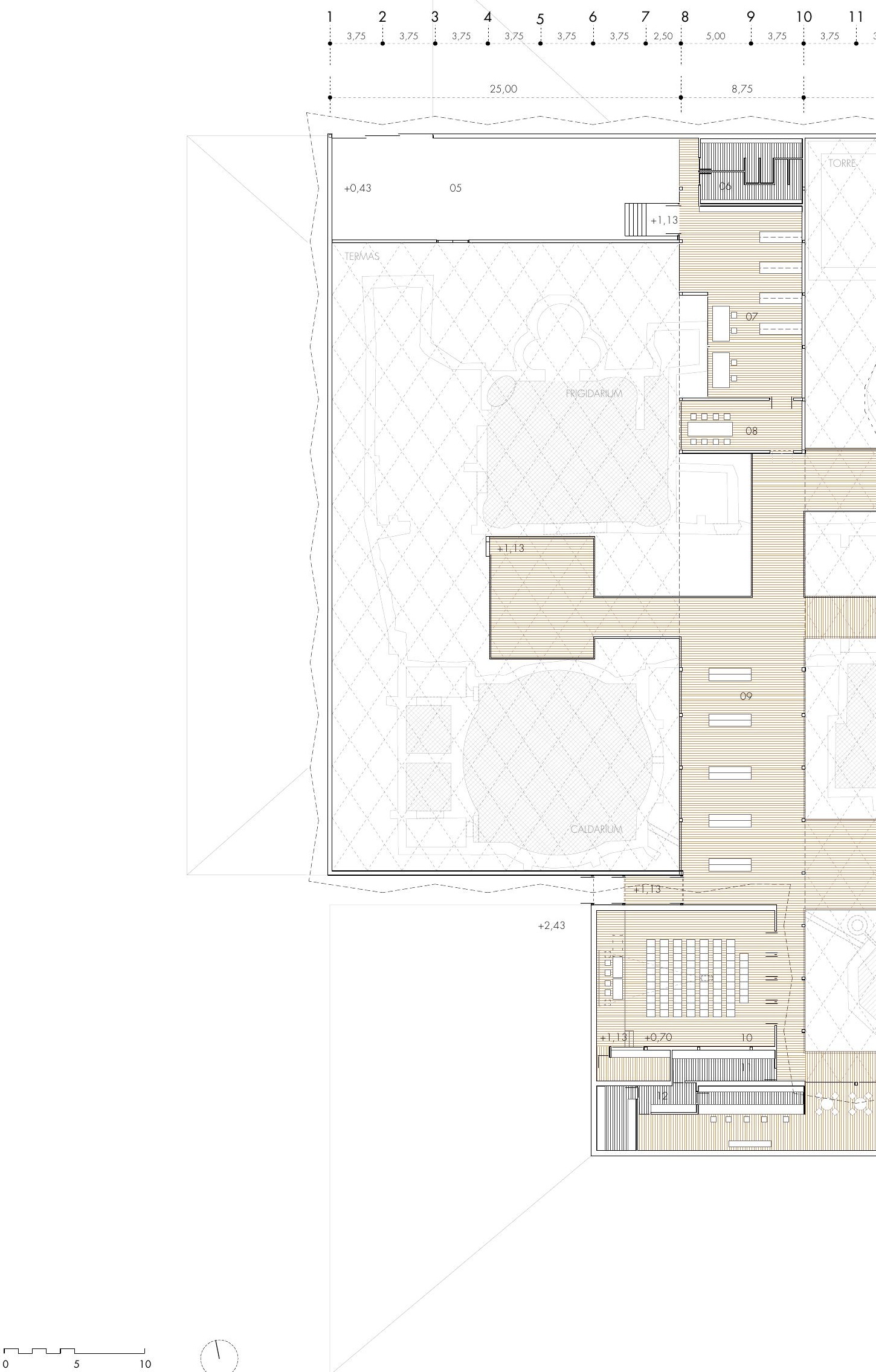
$\begin{array}{lllllllllllllllll}12 & 13 & 14 & 15 & 16 & 17 & 18 & 19 & 20 & 21 & 22 & 23 & 24 & 25 & 26 & 27 & 28\end{array}$
22,50
22,50
22,50

(1i

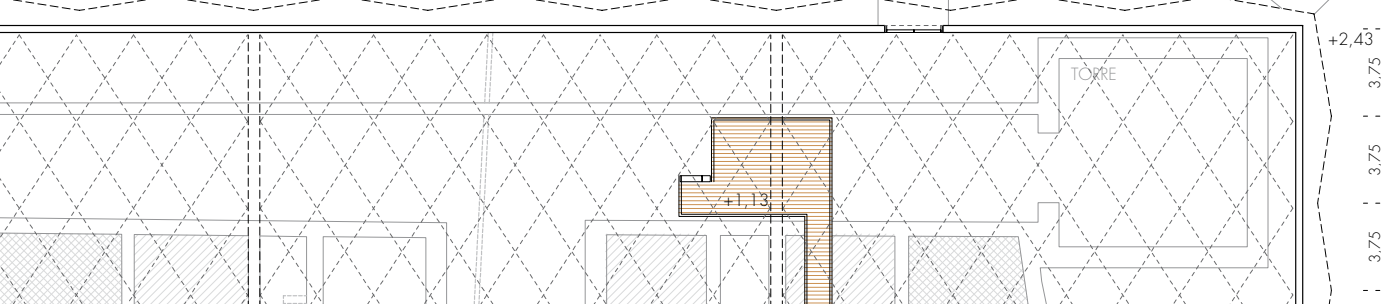

- B

- C

. D

. E

(D)

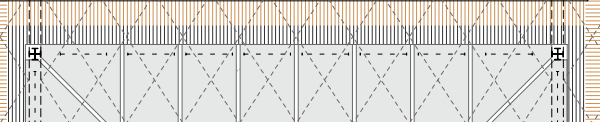

- $G$

.

ch

2

.- 1

- $k$

- L

$i$
i.
it

- M

... N

(n)

M. P

- Q

. $R$

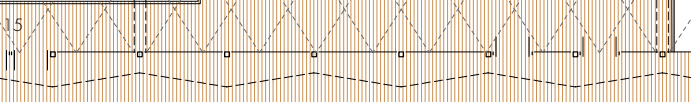

. $\mathrm{s}$ 

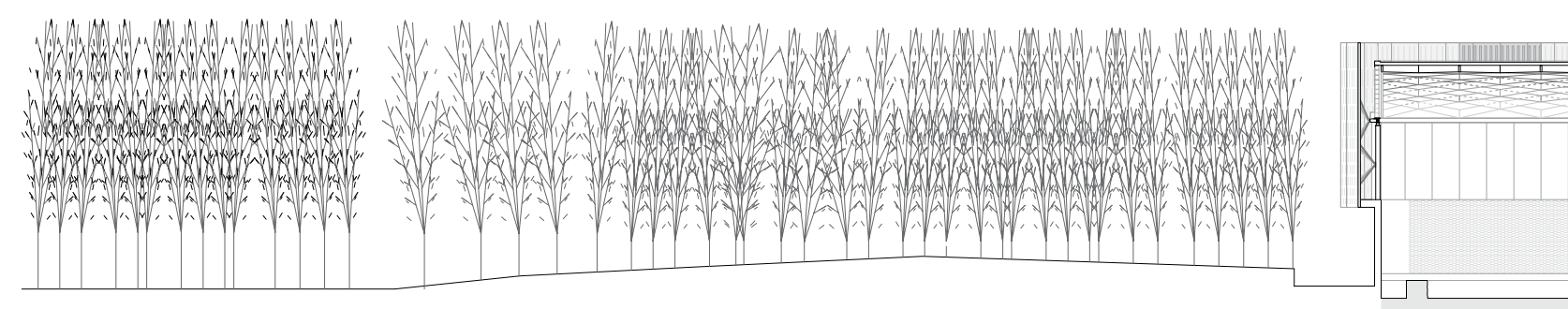

SECCIÓN 1-1' LONGITUDINAL. PABELLÓN DE TALLERES, ALMACENES Y OFICINAS

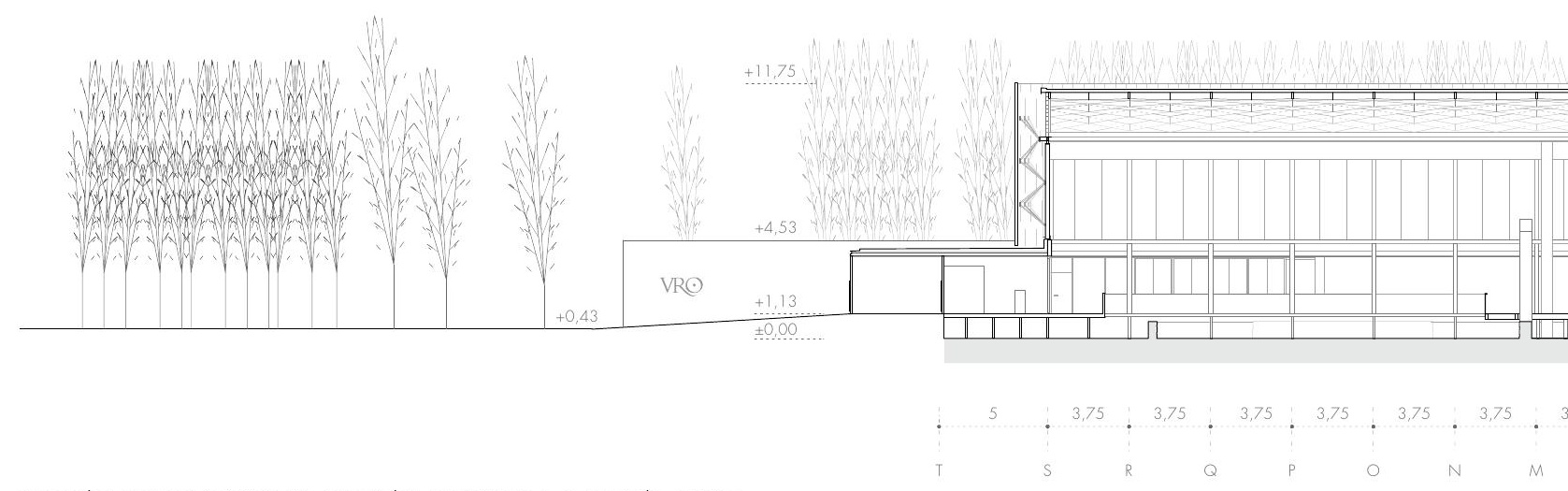

SECCIÓN 2-2' LONGITUDINAL. PABELLÓN DE ENTRADA. CAFETERIA, TIENDA

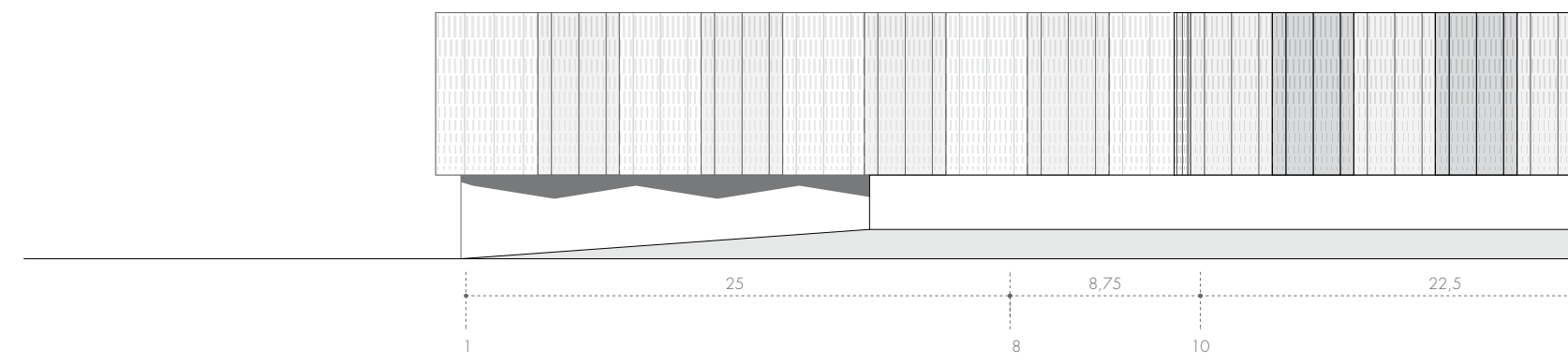

ALZADO PRINCIPAL DE ENTRADA A YACIMIENTO

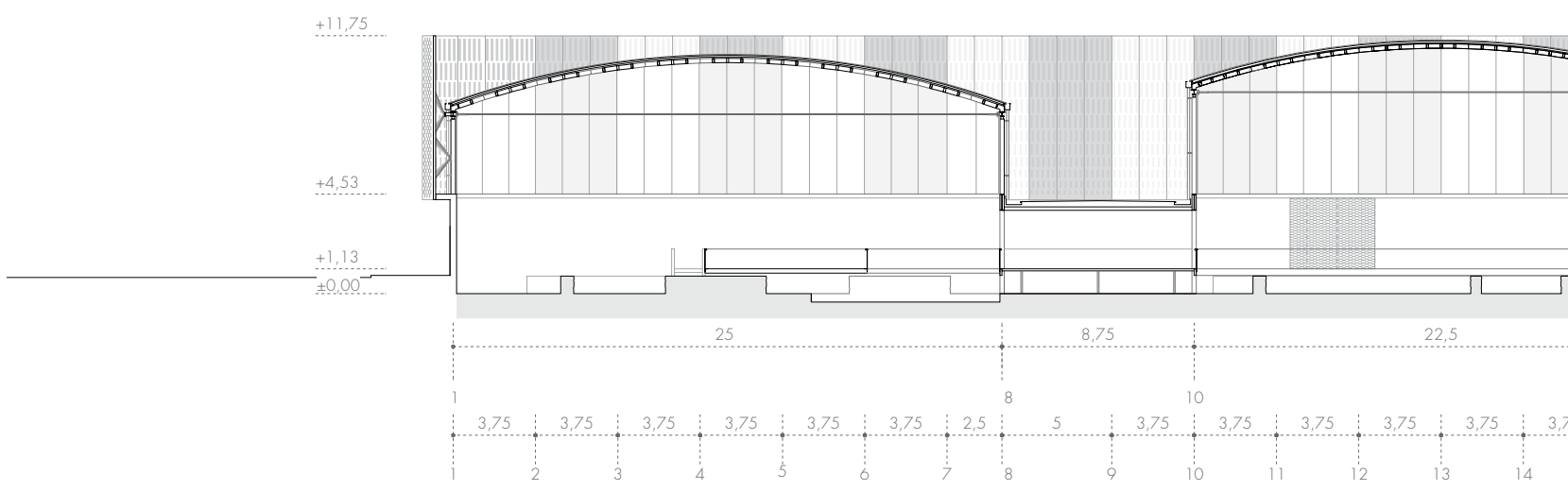

SECCIÓN 3-3' TRANSVERSAL

$0 \sqrt{5}$ 


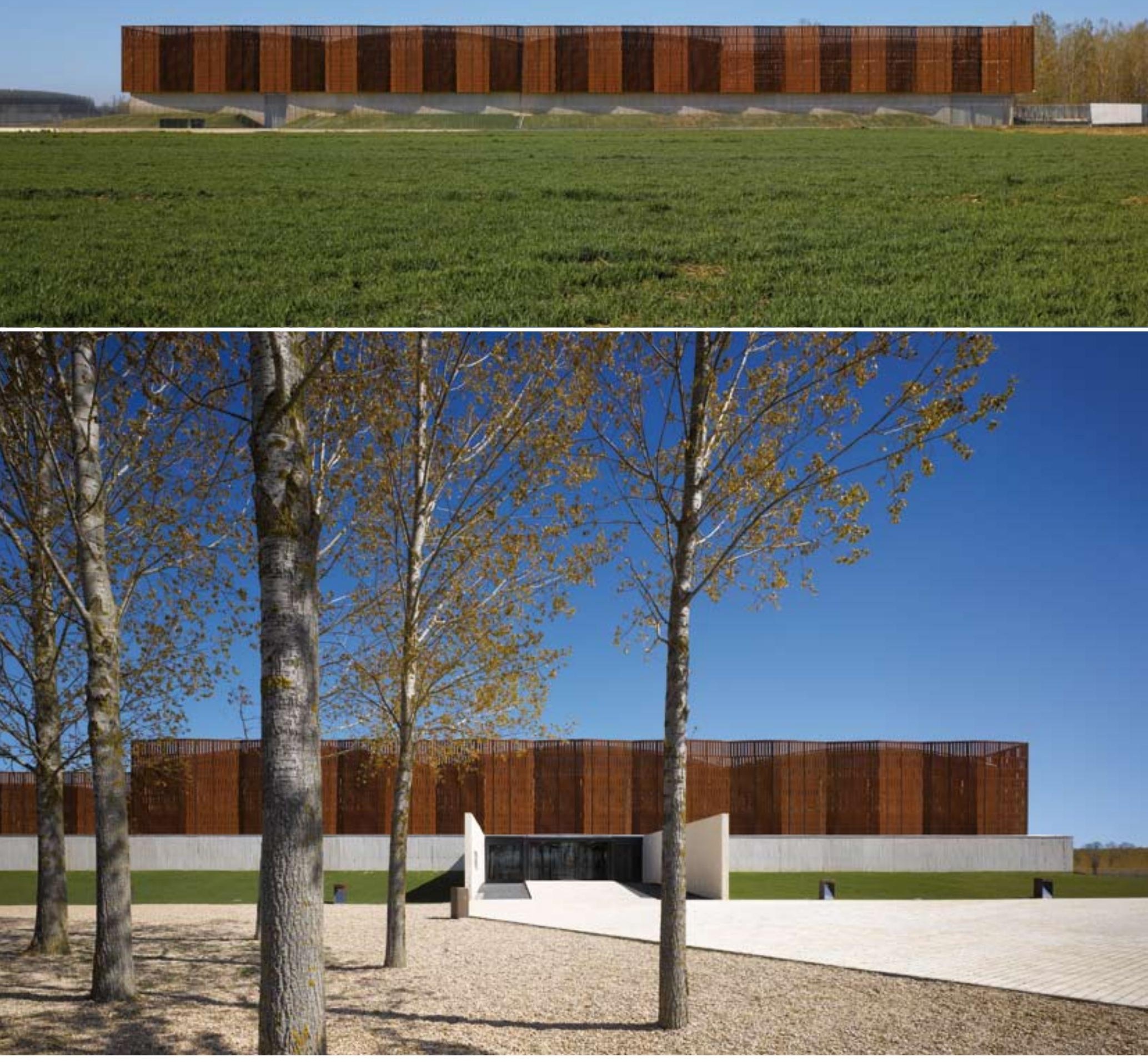

Imagen exterior y acceso al edificio. Fotos: Roland Halbe 

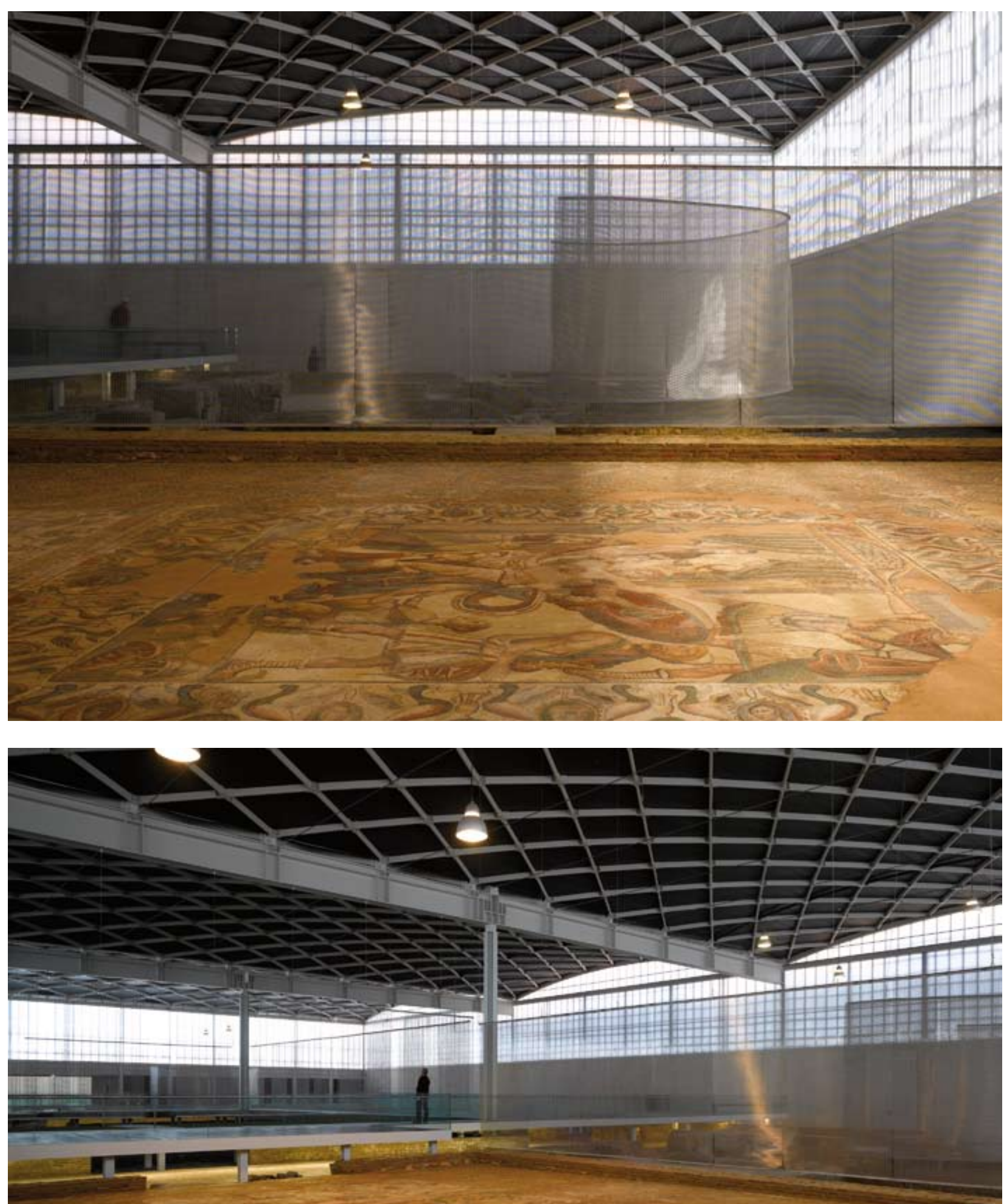

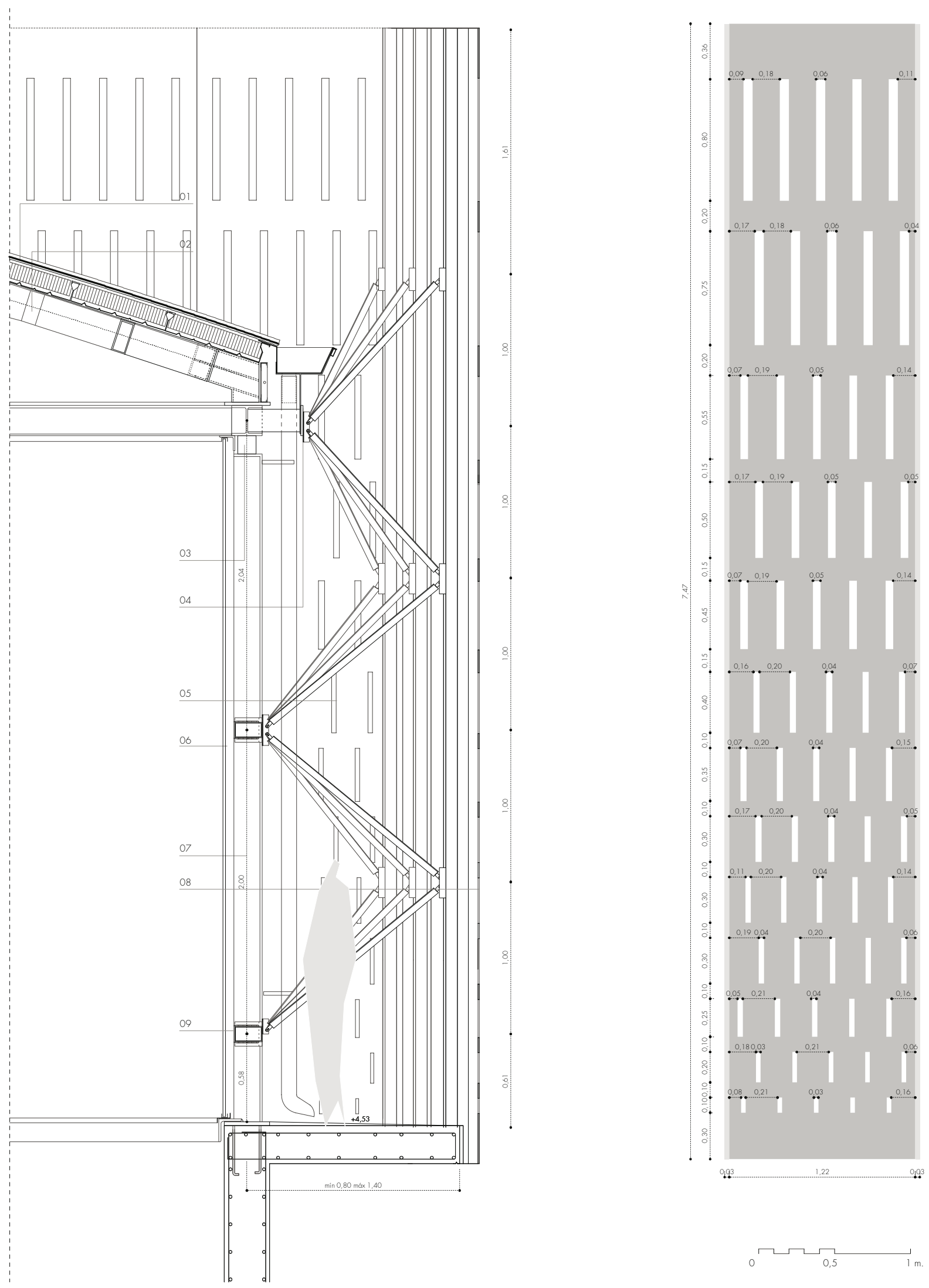

01. CUBIERTA DE ALUMINIO SISTEMA RIVERCLACK

02. ESTRUCTURA NERVADA DE PERFILES METÁlLCOS HUECOS 200.80.8 PINTADA

03. TUBO DE ACERO 120.120.4 CON IMPRIMACIÓN Y PINTURA INTUMESCENTE EF 120 COLOR RAL 9002

04. CHAPA DE ACERO DE e=4 MM PLEGADA, SOLDADA Y PERFORADA PARA RECIBIR SUBESTRUCTURA

05. SUBESTRUCTURA DIAGONAL FORMADA POR ANGULARES DE 45.4 PARA SUJECCIÓN DE LA CHAPA PERFORADA, CON IMPRIMACIÓN Y PINTURA ANTIOXIDANTE Y PINTURA INTUMESCENTE EF 120 COLOR RAL 9002 

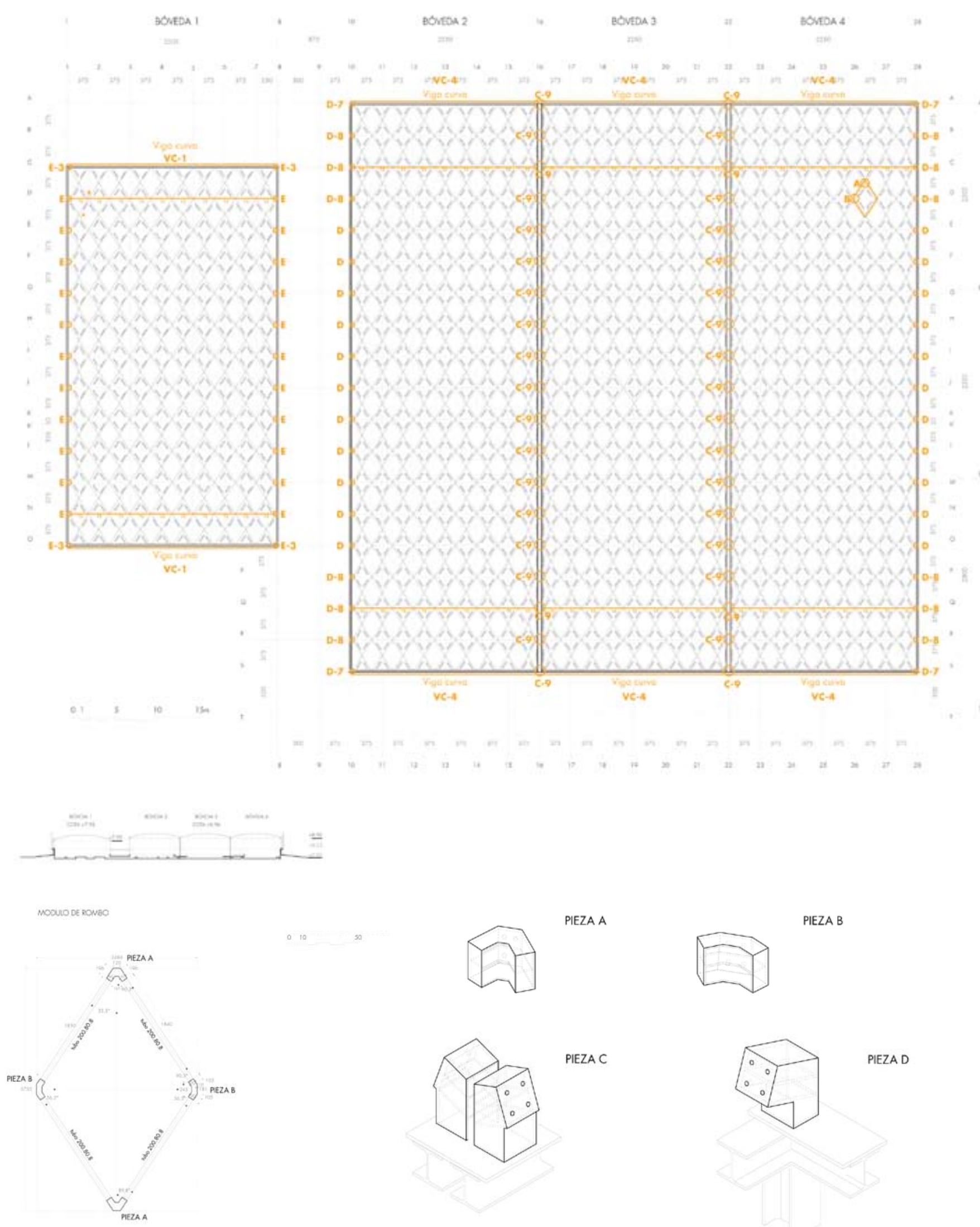

Estructura de cubiertas (replanteo) y axonométrica de piezas estructurales. Fuente: Paredes Pedrosa Arquitectos

La pieza de unión de los rombos es igual para los interiores y distinta para los que apoyan sobre las vigas, de tal forma que, como un gran mecano de piezas modulares, se construye una estructura tan amplia como se necesite 


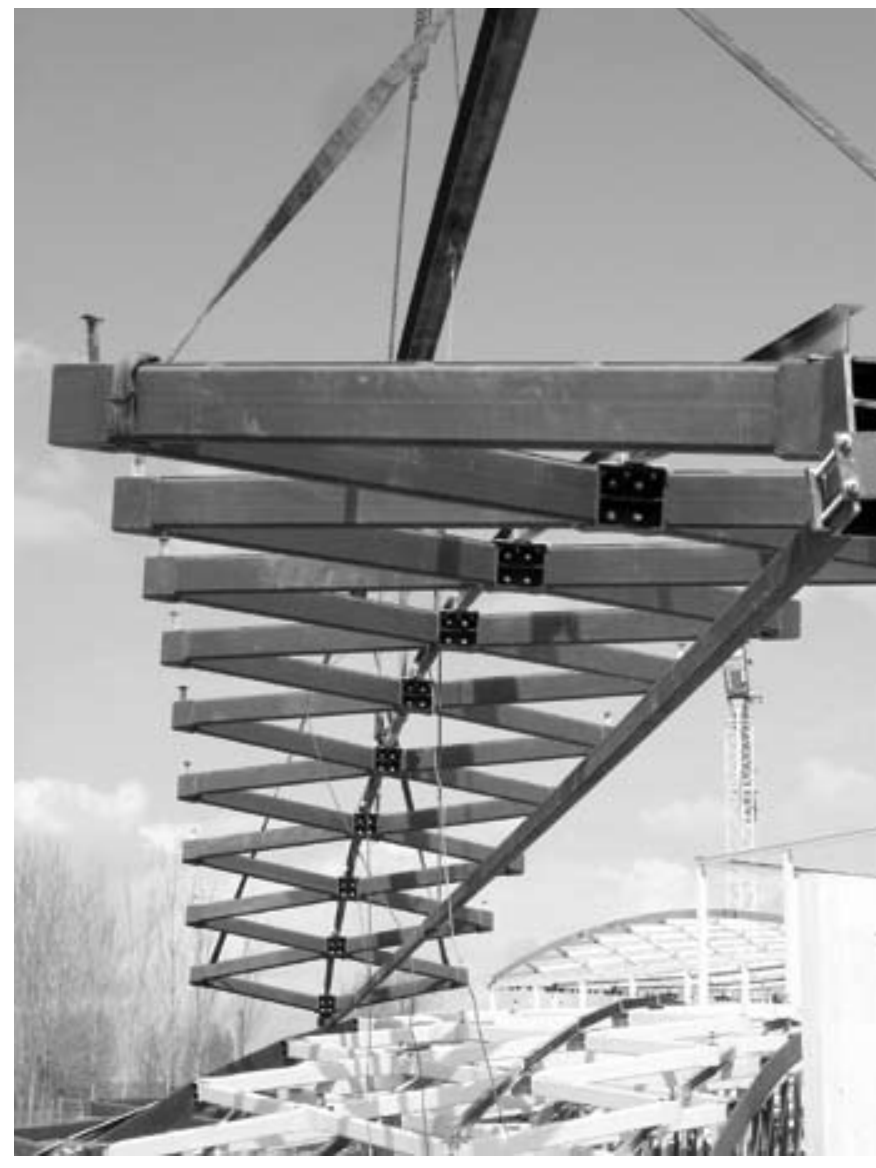

Izado y montaje de la estructura de cubierta. Fuente: Paredes Pedrosa Arquitectos

\section{ESTRUCTURA}

El proyecto de La Olmeda ha requerido la utilización de estructuras distintas que sin embargo tienen una presencia unitaria, pues todas ellas quedan vistas en el interior. El cerramiento que configura el perímetro exterior se construye con un muro de hormigón blanco estructural con encofrado de tablilla vertical que le aporta una textura vibrante. Sobre este muro se apoya tanto el cerramiento de acero corten como los pilares de acero que constituyen tanto el apoyo estructural de borde y el soporte de las fachadas traslúcidas perimetrales.

Además de la estructura perimetral, los elementos del programa, como la sala de audiovisuales, taquillas, tienda, cafetería, oficinas y talleres, precisan de espacios de dimensiones más convencionales, distintos de la estructura de pasarelas y diferentes de la cubierta general.

Resolver la estructura de la extensa cubierta no es sólo una cuestión de esfuerzos mecánicos, con el condicionante de los escasos puntos interiores de apoyo, sino que supone también una presencia desnuda protagonista del nuevo espacio arquitectónico de la villa romana. Debe evocar la cualidad espacial que un día tuvo la villa e incorporarla al valor arqueológico que hoy posee. Al observar el aspecto fabril de las naves utilizadas en otros yacimientos, cuyas cubriciones exhiben un carácter funcional de cerchas y chapas ligeras, inducia a plantear el diseño de la estructura como un elemento determinante de la nueva imagen de La Olmeda. De otra parte se debía resolver la construcción de una gran estructura en un medio rural lejos de fabricantes e industrias y tener como medio de izado una única grúa en el centro del yacimiento, que no debía ser pisado. Todo ello llevó a desarrollar un sistema constructivo modular prefabricado en taller.

Para cubrir todo el recinto, se proyectaron cuatro membranas abovedadas metálicas con retícula romboidal formada por tubos rectangulares unidos entre sí por los vértices con piezas especiales de unión y tornillos de alta resistencia, que permitían un ensamblaje cómodo in situ. Cada rombo se considera empotrado en sus vértices y articulado con los contiguos. La pieza de unión de los rombos tubulares de acero es igual para los rombos interiores y distinta para los que apoyan sobre las vigas, de tal forma que, como un gran mecano de piezas modulares, se construye una estructura tan amplia como se necesite.

De esta manera se resolvió asimismo el problema del transporte de las piezas romboidales de acero por medios convencionales y la propia estructura de acero podía quedar vista como un gran artesonado abovedado. Las bóvedas de $22,5 \mathrm{~m}$ de luz y $75 \mathrm{~m}$ de largo se apoyan perimetralmente en vigas también metálicas que a su vez descansan sobre pilares de acero separados 3,75 m en todo el perímetro y en cuatro grandes pilares en cruz dispuestos en el patio central. 


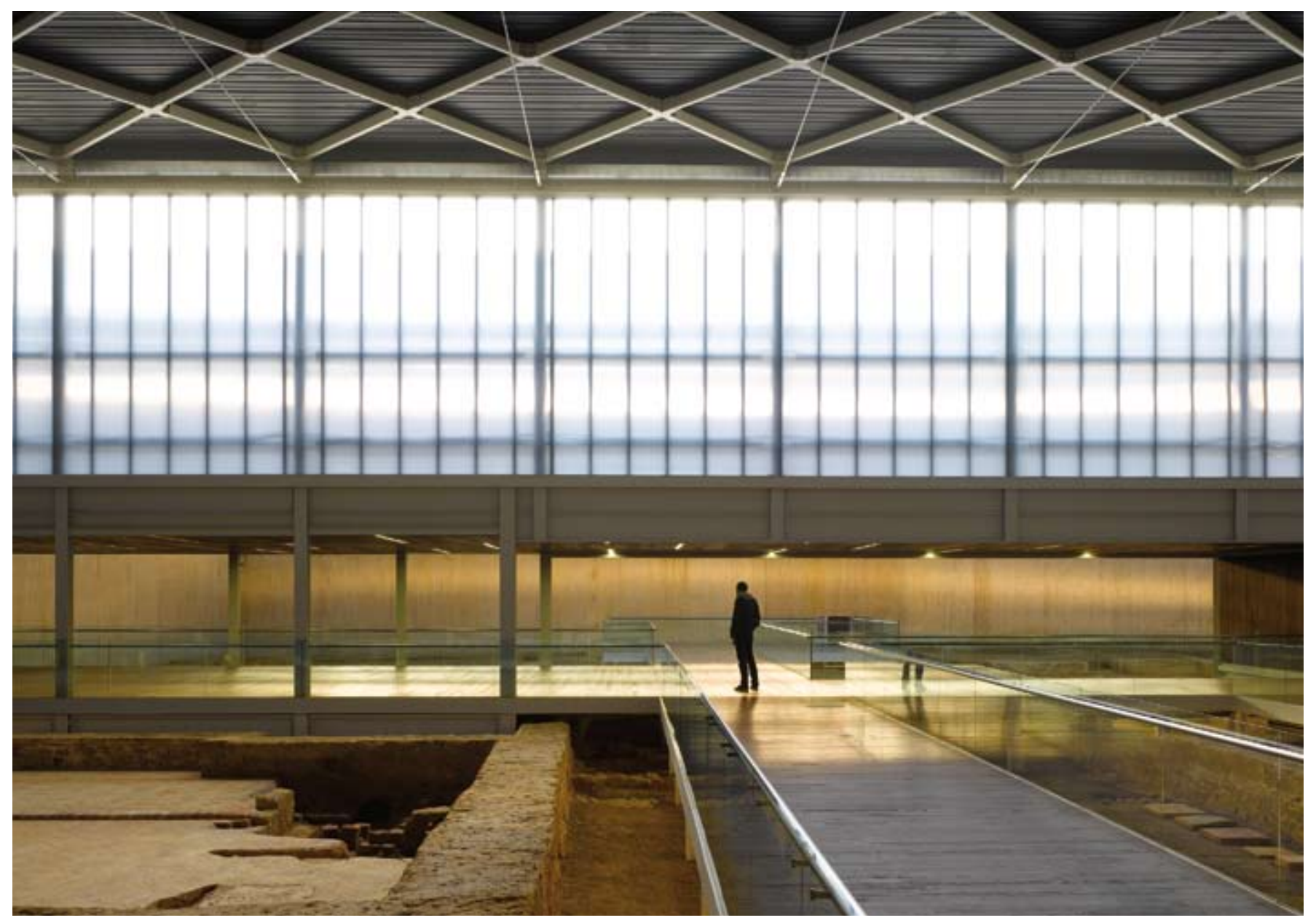

La pasarela por la que el visitante recorre la villa se apoya en una red de pilares que sortean los pavimentos protegidos y hacen compatible las geometrías de las estancias y del recorrido. Foto: Roland Halbe

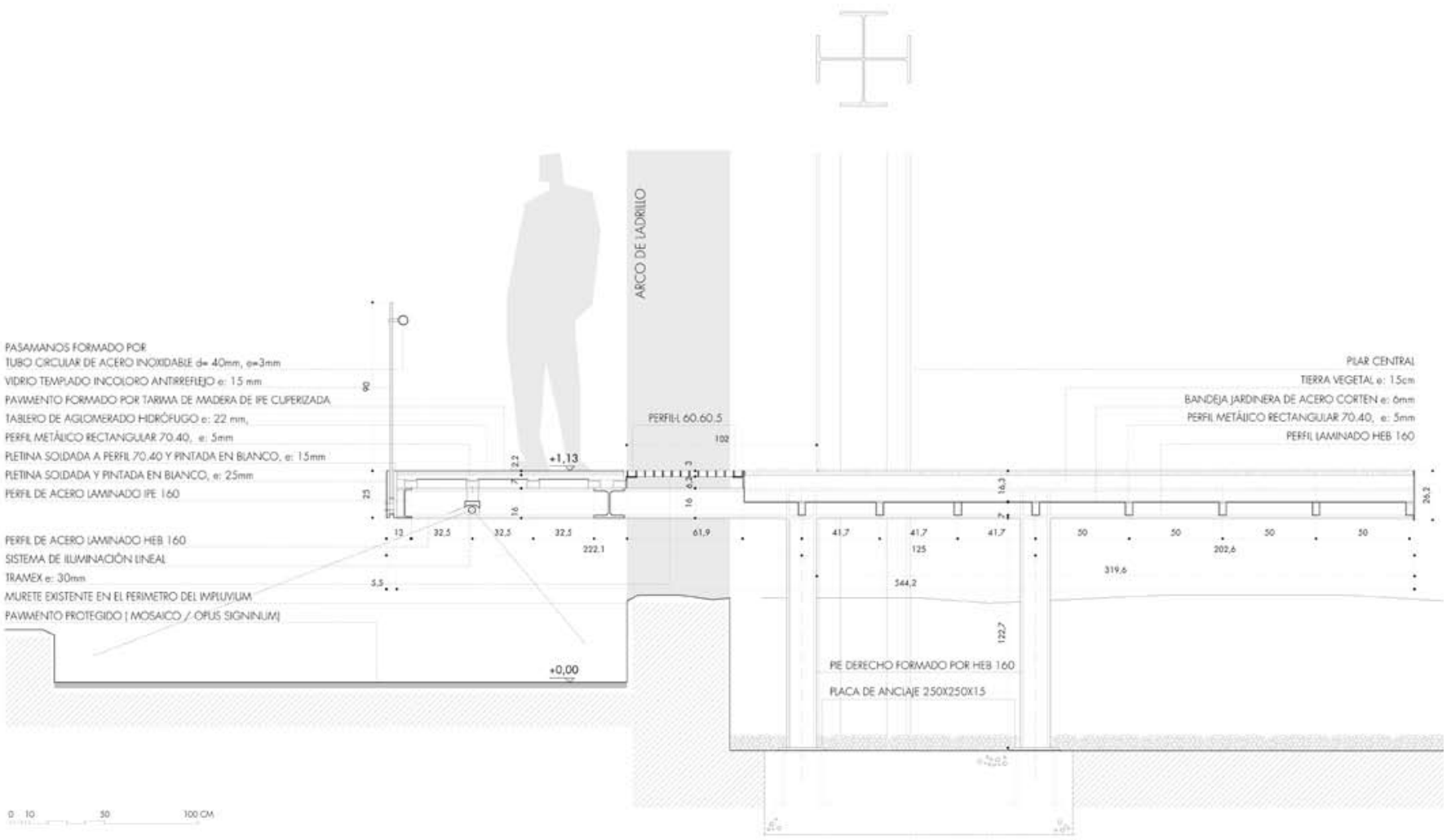




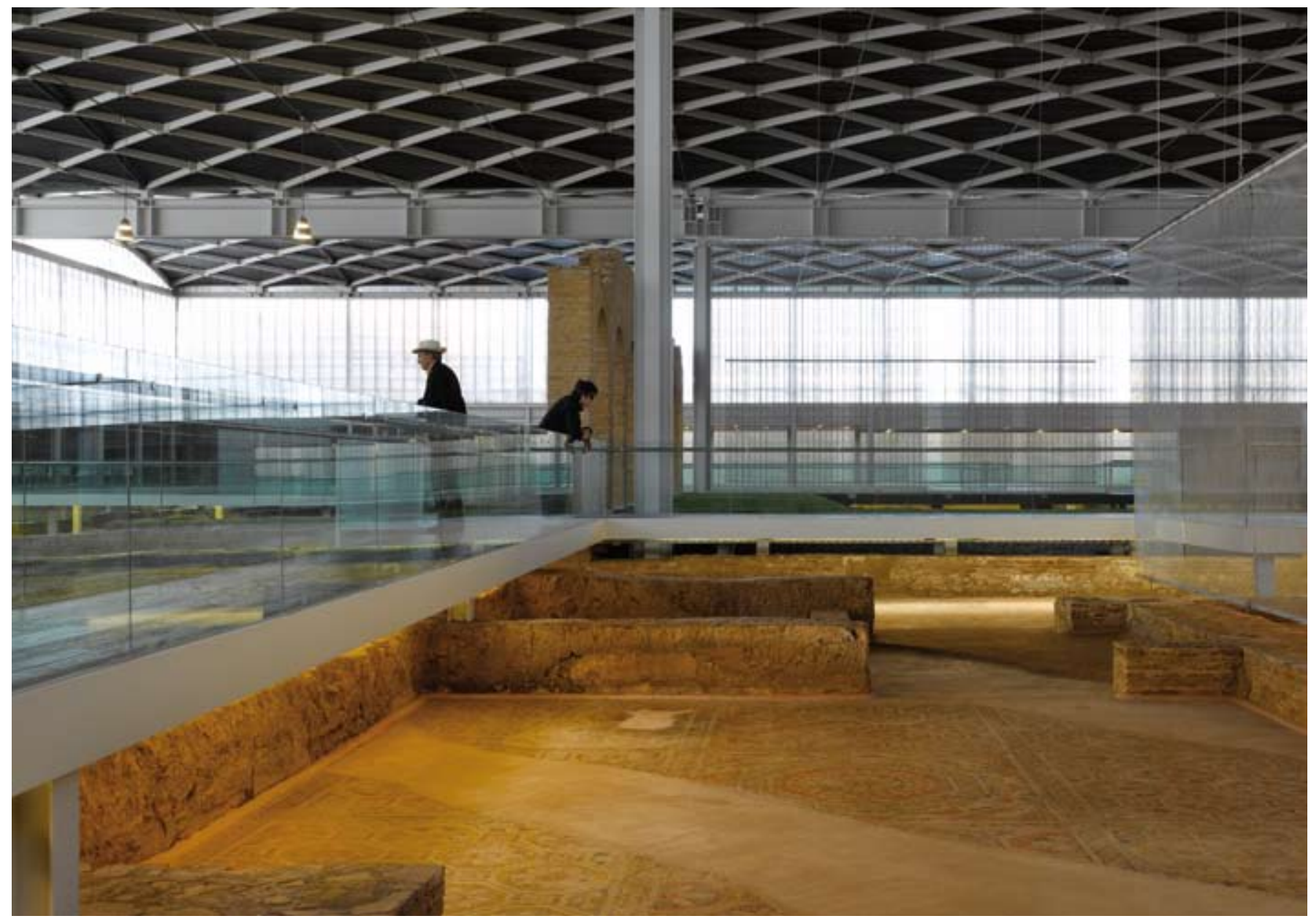

Visitantes contemplan los mosaicos desde la pasarela. Foto: Roland Halbe

Los cuatro apoyos centrales marcan las esquinas del antiguo patio de la villa y dos vigas compuestas de $107 \mathrm{~cm}$ de canto reciben la estructura de piezas romboidales atornilladas. Los pilares dejan completamente libres los mosaicos geométricos del peristilo. Exteriormente las estructuras abovedadas configuran la cubierta que, aislada y ventilada, se reviste de chapa de aluminio e interiormente quedan vistas.

La pasarela por la que el visitante recorre la villa, un plano horizontal levantado 1,15 $\mathrm{m}$ respecto de la cota de los mosaicos, se apoya en una red de pilares que sortean los pavimentos protegidos y hacen compatible las geometrias de las estancias y del recorrido. Donde no se encuentra apoyo, como en el deambulatorio del patio, integramente pavimentado de mosaicos, se ha recurrido a una estructura que se apoya en el interior del patio y vuela sobre los mosaicos utilizando bandejas ajardinadas de acero corten, que evocan el verdor del antiguo patio, como contrapeso a la pasarela en voladizo. Entre las bandejas y la pasarela de madera una banda de tramex sobre el muro romano establece la separación y permite la transparencia de la estructura.

\section{NOLI ME TANGERE}

El lema de nuestra propuesta de concurso fue Noli me Tangere, no tocar los muros romanos, no sólo por razones de conservación de los restos arqueológicos. Construir una nueva arquitectura independiente de la villa fue una de las premisas del proyecto. Que la huella de la villa romana quedara libre dentro de un espacio amplio formalizado por una cubierta ligera que pareciera flotar sobre ella era el reto.

Fuera de los muros perimetrales romanos era posible construir el nuevo cerramiento envolvente de hormigón pues no era previsible la aparición de ampliaciones ni añadidos a la planta original romana y de hecho no aparecieron durante la excavación de las zanjas y la construcción del drenaje perimetral. Sin embargo cualquier intervención en su interior debía no tocar ni muros ni mosaicos. Asi el pabellón de acceso al museo que configura el programa funcional se proyecta fuera de los muros romanos en su cara sur y el resto del programa se sitúa en la franja entre la villa y las termas sin interferir con la planta romana. Ambos ámbitos, villa y termas, debian quedar exentos e independientes del nuevo espacio construido.

El proceso de construcción comenzó con un aparente paso atrás en el tiempo y muros, pavimentos y mosaicos volvieron a ser enterrados. Previamente se protegieron los mosaicos con capas sucesivas de arena seca para controlar su grado de humedad, después con una manta de geotextil y, sobre ésta, bloques de poliestireno hasta igualar la altura de los muros romanos de ladrillo. Finalmente un entablamento de madera hidrófuga protegió el yacimiento durante las obras. 
Se desmontaron entonces las cubiertas provisionales que cubrieron la excavación y el espacio quedó abierto de nuevo a la lluvia y al viento. Una única grúa se colocó en el punto central del patio donde no se esperaba interferir con su cimentación los restos arqueológicos, pues en su origen era un jardin, y durante las obras ninguna maquinaria pesada se utilizó sobre el yacimiento. Las obras se acometieron desde el exterior de la villa, con maquinaria ligera y fueron lentas y complejas. Los cuatro altos pilares de acero en las esquinas del patio se izaron como apoyo de las vigas, también de hierro, que longitudinalmente constituyen el apoyo de las bóvedas que flotan sobre el yacimiento. El segundo sistema de pequeños pilares puntuales sorteaba los muros romanos para apoyo de la pasarela que, en una cota sobreelevada sobre éstos, llevaría a los visitantes a admirar los mosaicos. Varió durante la obra la posición de varios de ellos pues aparecieron trazas no contempladas en el levantamiento topográfico previo.
El proceso para completar la estructura fue largo y complejo. Casi olvidamos las imágenes y colores de los mosaicos protegidos bajo una gran trinchera si no fuera por alguna visita de Javier Cortes a las obras, que nunca hizo un comentario de impaciencia o duda sobre el proceso y alguna vez llegó con una caja de moras cogidas por él mismo en los alrededores como regalo. Durante la ejecución de la obra la presencia también de José Antonio Abásolo aseguraba la integridad del yacimiento y nos resolvía incertidumbres y preguntas. Cerrajeros, carpinteros y pintores trabajaron en unas condiciones atípicas, en un paraje despoblado, sobre los restos del pasado y sin apoyarse sobre ellos.

Tras las obras de construcción se desmontaron el entablamento y las protecciones sobre los mosaicos y con medios manuales se retiró lentamente la arena esparcida sobre ellos. Finalmente las primeras teselas quedaron a la vista tras los meses de obras

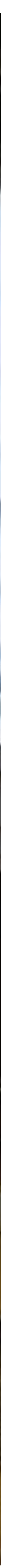

Cafetería. Foto: Roland Halbe 
y ese momento se asemejaba a un nuevo descubrimiento. Los oficios de la construcción se sustituyeron por mosaicistas que limpiaron cuidadosamente el yacimiento mientras se acometía la museografía e iluminación del redescubierto yacimiento, ya visible en su totalidad.

Exteriormente se acometieron las obras del aparcamiento y accesos y el ajardinamiento del talud que arropa el muro de hormigón. Interiormente se finalizaron los remates y con el otoño la gran superficie de las cubiertas abovedadas comenzó a recoger las primeras Iluvias. De nuevo el agua se lleva hacia las cuatro esquinas del patio central y se conduce naturalmente, al no poderse cruzar los muros arqueológicos, por el antiguo canal romano hacia el exterior. No tocar la villa romana sino coexistir con ella dictó tanto aspectos materiales como conceptuales.

\section{EL PASO DEL TIEMPO}

La Olmeda fue una gran villa rural, pars rustica, del bajo imperio que condicionó el territorio, social y culturalmente, durante casi dos siglos. Tras su desaparición a finales del siglo IV, tal vez como consecuencia de un incendio que provocó su derrumbe y cuyas huellas son visibles sobre algunos mosaicos, hasta el día de su descubrimiento casual en julio de 1968, permaneció dormida bajo una loma entre sembrados y choperas. Dieciséis siglos pasaron sobre ella hasta aparecer en otro tiempo que reclamaba su estudio y musealización. Visitar ahora la villa de La Olmeda es, de alguna manera, visitar un tiempo pasado.

Sin embargo los años transcurridos desde 1968 a 2009, cuando finalmente la villa se inaugura, son un recorrido jalonado de episodios que deben ser recordados por su carácter pionero y experimental. Su apertura al público, en 1984, representa el primer proyecto integral y la primera experiencia en España de cubrición de los restos de una villa. Según avanzaban las excavaciones se construyeron cubiertas para el yacimiento, de carácter temporal, pero que prolongaron su utilización durante veinte años, en los que se simultaneaba la visita pública con trabajos de recuperación de los mosaicos y excavación. Esta cubierta se realizó con placas de fibrocemento y placas traslúcidas de poliéster que permitian su iluminación cenital, con apoyos y cerchas metálicos. Se empezó a construir desde el ángulo noroeste, paralelamente a las primeras labores de consolidación y restauración de muros y mosaicos.

Inicialmente sólo se pensó en una cubierta y no en un cerramiento lateral, que fue añadido posteriormente. Por su carácter provisional y por la escasa planificación con la que se llevó a cabo, no se pudo evitar una apariencia de fábrica o de nave industrial. Volumétricamente, el sistema de cubierta elegido tenía forma de tejados a dos aguas estructurados siguiendo la disposición de la planta de la villa. Las estructuras de estas cubiertas, al ser demasiado bajas, producian un interior contaminado vi-
El lema de nuestra propuesta de concurso fue Noli me Tangere; no tocar la villa romana sino coexistir con ella dictó tanto aspectos materiales como conceptuales

\section{Villa romana La Olmeda. Cronología}

1968: Javier Cortes descubre los primeros restos de la villa. Comienza, a su cargo, la excavación arqueológica

1980: Javier Cortes dona la villa y sus terrenos a la Diputación de Palencia

1981-1984: Construcción gradual de cubiertas para proteger la excavación arqueológica

1984: Se abre al público el yacimiento

1984-2004: Continúan las excavaciones

2000: Concurso de ideas para adecuar el yacimiento de La Olmeda

2004: Se abren al público las termas

2004: Segunda fase del concurso. Primer premio: Paredes Pedrosa Arquitectos

2005: Se cierra la villa al público y comienzan en noviembre las obras 2009: El 3 de abril se abre el nuevo edificio al público

2009: El 4 de noviembre la Reina Sofia inaugura la v illa Romana La Olmeda

RESOLUCIÓN de 14 de noviembre de 1994 de la Dirección General de Patrimonio y Promoción Cultural, de la Consejería de Cultura y Turismo, por la que acuerda tener por incoado el expediente de declaración de bien de interés cultural a favor del yacimiento de La Olmeda en Pedrosa de la Vega (Palencia). Boletín Oficial del Estado n 46, jueves 23 de febrero 1995, p. 6359

Bien: VILLA ROMANA La OImeda Comunidad Autónoma: Castilla y León

Provincia: Palencia

Municipio: Pedrosa de la Vega

Categoria: Zona Arqueológica

Código: (R.I.) - 55 - $0000451-00000$

Registro: (R.I.) REGISTRO BIC INMUEBLES: Código definitivo

Fecha de incoación: 25-11-1994

Fecha de declaración: 03-04-1996

Fecha Boletín incoación: 23-02-1995

Fecha Boletín declaración: 10-04-1996

Disposición: DECRETO 


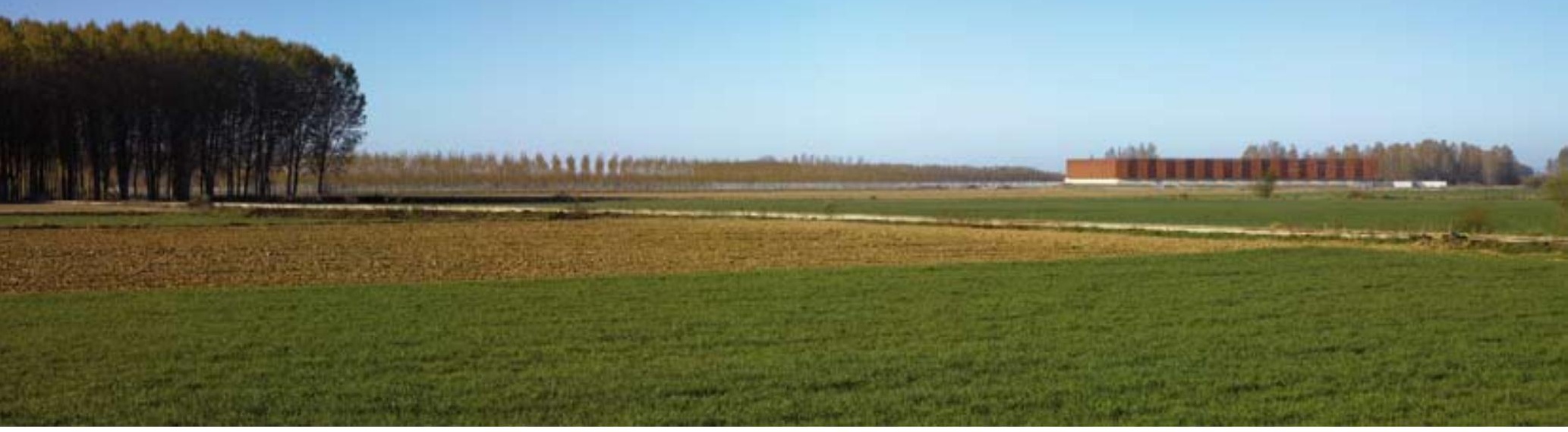

Edificio en el paisaje. Foto: Roland Halbe

sualmente por diversos elementos metálicos, que rompian el espacio interno y restaban visibilidad y diafanidad. Pese a todo, estas construcciones provisionales permitieron hasta el año 2005, cuando empiezan las obras del museo, conservar y proteger los restos arqueológicos y ser visitados y divulgados.

Conceptualmente en la nueva intervención arquitectónica de La Olmeda necesariamente la antigüedad se confronta con la modernidad y la arqueología con los nuevos criterios museísticos. La Olmeda vuelve a ser pionera a la hora de proponer una musealización integral del yacimiento. No sólo se debe contemplar correctamente los mosaicos sino transmitir la sensación de visitar un espacio arquitectónico del pasado.

Se asciende por la rampa que nos recuerda el montículo que ocultó la villa y que lleva al visitante a una cota más alta desde la que se inicia el recorrido con la presencia permanente de la excavación romana a nivel del terreno. Tras la entrada, el cortaviento acristalado funciona como exclusa al clima y al tiempo y da paso al vestíbulo mirador que alberga los necesarios servicios museísticos: control, taquillas, aseos y tienda. El vestíbulo es comprimido en altura y la madera oscura enlistonada cubre todas las superficies excepto en su frente donde un ventanal continuo se abre hacia el espacio del yacimiento.

El recorrido se articula alrededor del patio jardin y comienza en la entrada sur de la villa flanqueado por la huella de las dos torres octogonales. Se rodea el patio, se contemplan los mosaicos y el oecus, desde un ensanchamiento de la pasarela, se convierte en una gran estancia de paredes metálicas. Tras pasar al peristilo norte, la pasarela rodea el patio y las bandejas ajardinadas. Sus frentes este, norte y oeste, sin arcos, se reconstruyen también con velos metálicos. Dejando atrás el patio, la pasarela conduce a las termas. Previamente se detiene en un ensanchamiento abierto entre ambos espacios, villa y termas, de techo y paramentos de listones de madera oscura, destinado a área de exposiciones. Una vez en las termas la pasarela pasa a ser un balcón central para contemplar la planta lobulada y los estratos de pavimentos que muestran la ingeniería romana bajo los delicados mosaicos.

El área interna del museo, taller de restauración, vestuarios y oficinas se ubican al norte con ventanales hacia las termas y disponen a su vez de entrada directa desde el exterior a través de un patio de trabajo. El auditórium de 110 plazas se dispone al final de la visita y vinculado al espacio expositivo. Una vez de regreso al vestíbulo, la cafetería supone el final del recorrido y se une al espacio de acceso incorporándose al ventanal acristalado sobre el yacimiento. De esta manera el programa funcional se infiltra entre los muros romanos, sin tocarlos, pero enlazados mediante la pasarela del recorrido.

Para la villa romana de La Olmeda comienza ahora otro tiempo que ha transformado no sólo la villa sino el paisaje y la actividad del lugar al aparecer autocares y visitantes que la sitúan en nuestros días. A la entrada del camino de acceso y entre los sembrados, una estela de una pieza de acero corten, con las iniciales VRO perforadas, nos recuerda el paso del tiempo.

Agradecimiento: $\mathrm{PH}$ reconoce la desinteresada colaboración del fotógrafo Roland Halbe al ceder las imágenes para su publicación. 


\section{FICHA TÉCNICA}

Proyecto

Villa romana La Olmeda

Ubicación

Pedrosa de la Vega (Palencia, España)

\section{Arquitectos}

Ángela García de Paredes, Ignacio G. Pedrosa

\section{Colaboradores}

Clemens Eichner, Álvaro Rábano, Eva Urquijo, Andrea Franco-

netti, Eva M. Neila, arquitectos

\section{Dirección de obra}

Ángela García de Paredes, Ignacio G. Pedrosa

\section{Dirección de ejecución}

Luis Calvo

\section{Consultores}

Alfonso G. Gaite. GOGAITE, S.L., estructura

Nieves Plaza, instalaciones

Intervento, iluminación

SONO Tecnología Audiovisual, S.L., musealización

\section{Constructora}

UTE la Olmeda

\section{Superficie construida}

$7.130 \mathrm{~m}^{2}$

\section{Propiedad}

Diputación de Palencia

\section{Financiación}

Diputación de Palencia

Junta de Castilla y León

Fundación Patrimonio Histórico de Castilla y León

Ministerio de Fomento

Fechas de proyecto y obra

Concurso fase 1: 2000

Concurso fase 2: 2004

Proyecto: 2005

Inauguración: 2009

\section{Presupuesto de obra}

$6.548 .600 €+$ IVA

\section{Fotografías}

Roland Halbe

\section{Bibliografía}

ABÁSOLO ÁLVAREZ, J. A; CORTES ÁLVAREZ DE MIRANDA, J.; PÉREZ RODRíGUEZ-ARAGÓN, F. (1997) La necrópolis Norte de La Olmeda (Pedrosa de la Vega, Palencia). Palencia: Diputación Provincial, 1997

BALIL, A. (1980) El héroe y las princesas. Actas I/ Congreso de Historia de Palencia, 1980, pp. 165-181

CHAVARRÍA ARNAU, A. (2006) Villas en Hispania durante la Antigüedad tardia. En W. AA. Villas Tardoantiguas en el Mediterráneo Occidental. Anejos A EspA. Madrid: CSIC, XXXIX, 2006, pp. 17-35

CORTES ÁLVAREZ DE MIRANDA, J.; DE PALOL, P. (1969) Una nueva villa romana en Pedrosa de la Vega. BSAA, XXXIII, 1969, pp. 232-236

CORTES ÁLVAREZ DE MIRANDA, J.; RíOS SANTOS, D. (1988) El Hipocaustum de la habitación número 3 de la Villa Romana de la Olmeda. Publicaciones de la Institución Tello Téllez de Meneses (PITTM), nº 58, 1988, pp. 7-27

CORTES ÁLVAREZ DE MIRANDA, J. (2008) Mosaicos en la villa romana de La Olmeda. Palencia: Diputación, 2008

DUNBABIN, K. (1999) Mosaics of the Greek and Roman World. New York: Cambridge University Press, 1999

FERNÁNDEZ CASTRO, M. C. (1984) Villas romanas en España. Madrid: Editorial Nacional, 1984

GORGES, J. G. (1979) Les villas hispano romaines: inventaire et problématique archéologiques. Bordeaux: Université, 1979

LANCHA, J. (1985) Le rinceau aux medaillons de la mosaïque d'Achille (Pedrosa de la Vega): essai d'interpretation. Mosaicos Romanos. Actas de la I Mesa Redonda Hispano-Francesa sobre Mosaicos Romanos. Madrid: Ministerio de Cultura, 1985, pp. 169-180

NOZAL CALVO, M.; PUERTAS GUTIÉRREZ, F. (1995) La terra sigillata paleocristiana gris en la villa romana de La Olmeda. Studia Archaeologica, 83, Universidad Valladolid, 1995

NOZAL CALVO, M.; RíOS SANTOS, D. (1997) Consolidación y restauración el ámbito termal. La habitación $n^{\circ} 34$ de la Villa Romana de La Olmeda. Publicaciones de la Institución Tello Téllez de Meneses (PITM), no 68, 1997, pp. 131-160

NOZAL CALVO, M.; CORTES ÁlVAREZ DE MIRANDA, J.; ABÁSOLO ÁlVAREZ, J. A. (2000) Intervenciones en los baños de la villa de Pedrosa de la Vega. Termas romanas en el occidente del imperio: II Coloquio Internacional de Arqueología en Gijón. Gijón: VTP Editorial, 2000, pp. 131-318

PALOL, P DE; CORTES ÁlVAREZ DE MIRANDA, J.; (1972) La villa romana de Pedrosa de la Vega (Palencia). Excavaciones de 1969 y 1970. Acta Arqueológica Hispánica, 7, Madrid, 1972

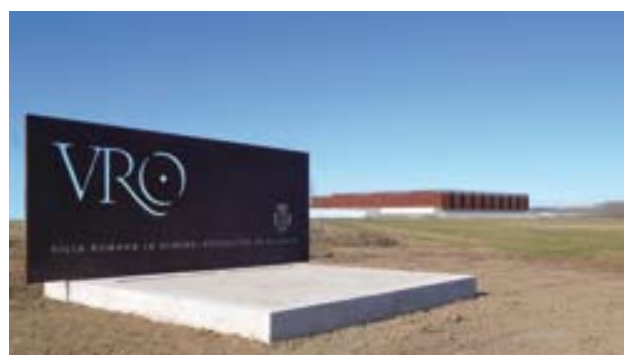

